\title{
AVALIAÇÃO DAS CONDIÇÕES MICROBIOLÓGICAS DE LEITE PASTEURIZADO TIPOS A, B e C, COMERCIALIZADOS NA CIDADE DE PIRACICABA, SP
}

\section{SUELY GOMES TAVARES}

Nutricionista

Orientador: Prof. Dr. CLAUDIO ROSA GALLO

Dissertação apresentada à Escola Superior de Agricultura "Luiz de Queiroz", da Universidade de São Paulo, para obtenção do título de Mestre em Ciências. Área de Concentração: Ciência e Tecnologia de Alimentos.

PIRACICABA

ESTADO DE SÃO PAULO - BRASIL

Abril/1996 
Dados Internacionais de Catalogação na Publicação (CIP)

DIVISÃO DE BIBLIOTECA E DOCUMENTAÇÃO - Campus "Luiz de Queiroz"/USP

Tavares, Suely Gomes

Avaliação das condiçōes microbiológicas de leite pasteurizado tipos A, B e C, comercializados na cidade de Piracicaba, SP / Suely Gomes Tavares. - - Piracica ba, 1996.

$84 p$.

Dissertação (mestrado) - Escola Superior de Agricultura Luiz de Queiroz, 1996.

Bibliografia.

1. Leite pasteurizado - Microbiologia 2. Leite pasteurizado - Análise - Piracica ba 1 . Titulo

CDD 637.1333 
AVALIAÇÃO DAS CONDIÇÕES MICROBIOLÓGICAS DE LEITE

PASTEURIZADO TIPOS A, B e C, COMERCIALIZADOS

NA CIDADE DE PIRACICABA, SP

SUELY GOMES TAVARES

Aprovada em 03.06.1996

Comissão julgadora:

Prof. Dr. Claudio Rosa Gallo

ESALQ/USP

Prof. Dr. Antonio Joaquim de Oliveira

ESALQ/USP

Prof. Dr. Wilson Roberto Soares Mattos

ESALQ/USP

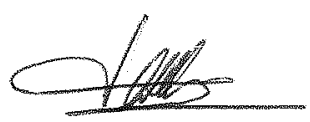

Prof. Dr. CLAUDIO ROSA GALLO

Orientador 
Dedico:

À Jorge Luiz e, meus filhos:

Luiz Antonio e Maria Tereza. 


\section{AGRADECIMENTOS}

Ao Prof. Dr. Claudio Rosa Gallo, pelo marcante incentivo.

Aos professores e aos colegas do Curso de Pós-Graduação do Departamento de Ciência e Tecnologia de Alimentos da Escola Superior de Agricultura "Luiz de Queiroz", pelo convívio saudável e pela motivação conjunta.

Aos funcionários do Departamento de Ciência e Tecnologia de Alimentos da Escola Superior de Agricultura "Luiz de Queiroz", pelos valiosos auxílios prestados.

À Coordenadoria de Aperfeiçoamento de Pessoal de Ensino Superior (CAPES), pelo auxílio concedido através de bolsa de estudos.

À Clotilde Maria Batochio Cunha, com amizade, pelos valiosos auxílios prestados.

À Maria José, com amizade, pelo apoio prestado.

A todos que, direta ou indiretamente contribuíram para o êxito deste trabalho. 


\section{SUMÁRIO}

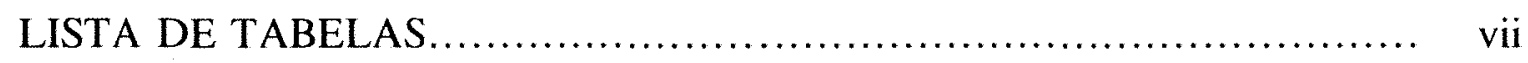

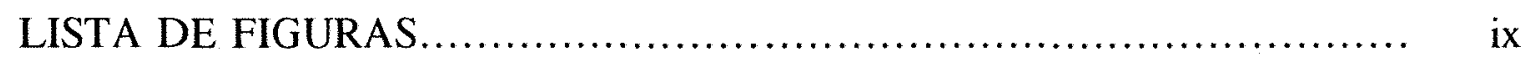

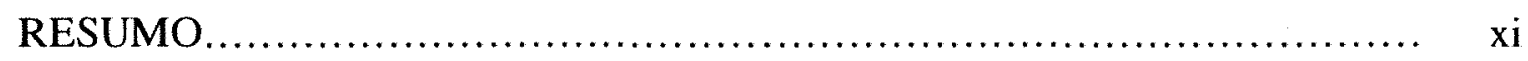

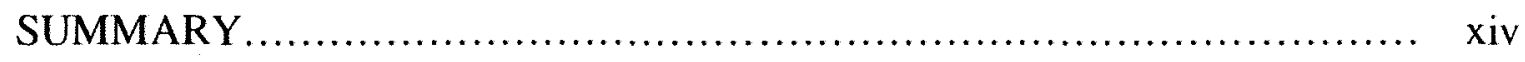

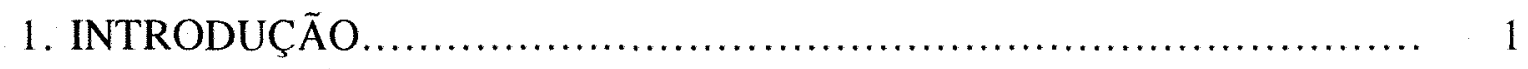

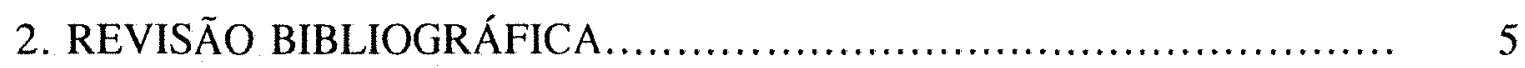

2.1. Qualidade microbiológica do leite para consumo humano............. 5

2.2. Microrganismos indicadores de contaminação fecal - coliformes...... . 6

2.3. Microrganismos Mesófilos, Termófilos e Psicrotróficos e/ou

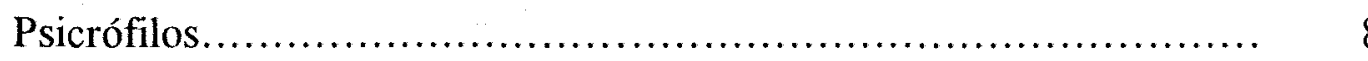

2.4. Pasteurização x carga microbiológica do produto................. 10

2.5. Fatores que interferem na qualidade higiênica do leite............ 17

2.6. Classificação do leite de consumo............................. 18

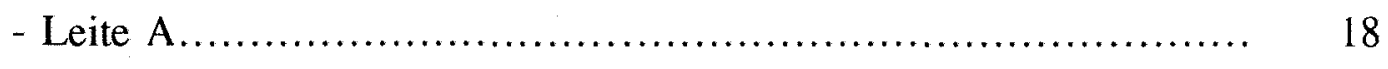

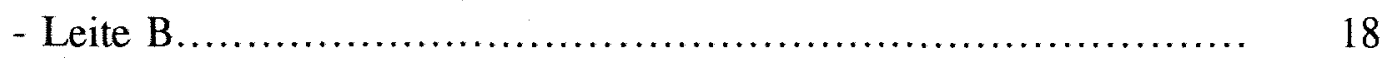

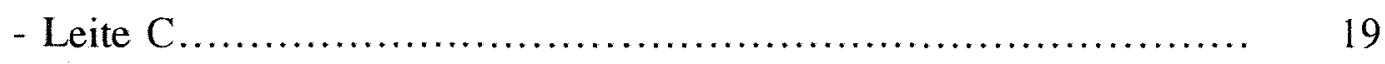

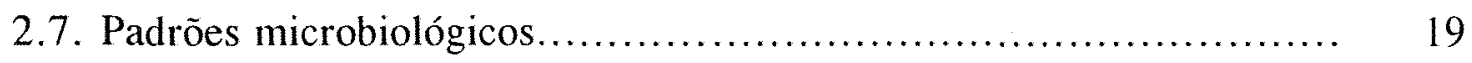


3. MATERIAL E MÉTODOS ............................................... 23

- Amostras................................................................ 23

- Meios de cultivo......................................................... 23

- Equipamentos......................................................... 23

- Outros................................................................ 24

- Obtenção das amostras................................................ 24

- Preparo das amostras.................................................. 25

4. RESULTADOS E DISCUSSÃO .......................................... 28

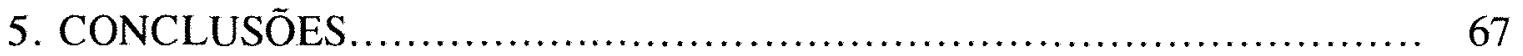

REFERÊNCIAS BIBLIOGRÁFICAS .................................. 69 


\section{LISTA DE TABELAS}

TABELA

Página

1 Porcentagens de amostras de leite pasteurizado tipos $\mathrm{A}, \mathrm{B}$ e $\mathrm{C}$, fora dos padrões, segundo as portarias 1/87 do Ministério da Saúde DINAL e 8/94 do Ministério da Agricultura - SIPA

2 Unidades Formadoras de Colônias (UFC/ml) de microrganismos mesófilos, termófilos e psicrófilos e/ou psicrotróficos nas 24 amostras de leite pasteurizado tipo A

3 Número Mais Provável (NMP) de coliformes/ml nas 24 amostras de de leite tipo A

4 Unidades Formadoras de Colônias (UFC/ml) de microrganismos mesófilos, termófilos e psicrófilos e/ou psicrotróficos nas 36 amostras de leite pasteurizado tipo $\mathrm{B}$

5 Número Mais Provável (NMP) de coliformes/ml nas 36 amostras de leite tipo B. 
6 Unidades Formadoras de Colônias (UFC/ml) de microrganismos mesófilos, termófilos e psicrófilos e/ou psicrotróficos nas 48 amos-

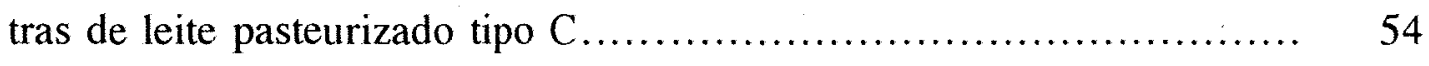

7 Número Mais Provável (NMP) de coliformes/ml nas 48 amostras de

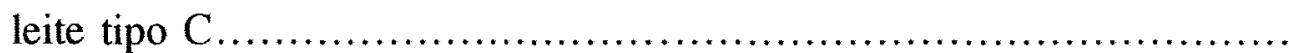




\section{LISTA DE FIGURAS}

FIGURA

1 Esquema do procedimento analítico

2 Porcentagens de amostras analisadas de leite pasteurizado tipo A, das marcas $A_{1}$ e $A_{2}$, que se apresentaram fora dos padrões DINAL (1987) e SIPA (1994) para microrganismos mesófilos (A) e SIPA (1994) para termófilos (B) e psicrófilos e/ou psicrotróficos (C)

3 Porcentagens de amostras analisadas de leite pasteurizado tipo A, das marcas $A_{1}$ e $A_{2}$, que se apresentaram fora das especificações dos padrões DINAL (1987) e SIPA (1994) para bactérias coliformes totais e fecais.

4 Porcentagens de amostras analisadas de leite pasteurizado tipo B, das marcas $B_{1}, B_{2}$ e $B_{3}$, que se apresentaram fora dos padrões DINAL (1987) e SIPA (1994) para microrganismos mesófilos (A) e SIPA (1994) para termófilos (B) e psicrófilos e/ou psicrotróficos (C) 
5 Porcentagens de amostras analisadas de leite pasteurizado tipo B, das marcas $B_{1}, B_{2}$ e $B_{3}$, que se apresentaram fora das especificações dos padrões DINAL (1987) e SIPA (1994) para bactérias coliformes totais e fecais

6 Porcentagens de amostras analisadas de leite pasteurizado tipo C, das marcas $C_{1}, C_{2}, C_{3}$ e $C_{4}$, que se apresentaram fora dos padrões DINAL (1987) e SIPA (1994) para microrganismos mesófilos (A) e SIPA (1994) para termófilos (B) e psicrófilos e/ou psicrotróficos (C)

7 Porcentagens de amostras analisadas de leite pasteurizado tipo C, das marcas $C_{1}, C_{2}, C_{3}$ e $C_{4}$ que se apresentaram fora das especificações dos padrões DINAL (1987) e SIPA (1994) para bactérias coliformes totais e fecais 
AVALIAÇÃO DAS CONDIÇÕES MICROBIOLÓGICAS DE LEITE

PASTEURIZADO TIPOS A, B e C, COMERCIALIZADOS

NA CIDADE DE PIRACICABA, SP

\author{
Autor: SUELY GOMES TAVARES \\ Orientador: Prof. Dr. CLAUDIO ROSA GALLO
}

\title{
RESUMO
}

Avaliaram-se as condições microbiológicas de leite pasteurizado, de marcas diferentes, sendo duas do tipo $\mathrm{A}$, três do tipo $\mathrm{B}$ e quatro do tipo $\mathrm{C}$, totalizando-se 24 amostras de leite tipo A, 36 de tipo B e 48 de tipo C.

As amostras coletadas, no comércio varejista de Piracicaba, SP, no período de janeiro a junho de 1995, foram submetidas à análise para verificação da presença de microrganismos mesofílicos, termofílicos, psicrofílicos e/ou psicrotróficos, coliformes totais e fecais, para comparação com os padrões do Ministério da Saúde - Divisão Nacional de Vigilância Sanitária de Alimentos (DINAL, 1987), órgão este que controla a qualidade do produto no comércio varejista.

Os resultados das análises mostraram que o leite pasteurizado das marcas $A_{1}$ e $A_{2}$ apresentou, respectivamente, $66,7 \%$ e $75,0 \%$ das amostras fora das 
especificações dos referidos padrões, para microrganismos mesófilos; a presença de coliformes totais em níveis superiores aos permitidos pelos padrões DINAL (1987), foi constatada em $33,3 \%$ e em $25,0 \%$ das amostras das marcas $A_{1}$ e $A_{2}$, respectivamente; não foram observados coliformes fecais nas duas marcas analisadas.

Para o leite tipo $\mathrm{B}, 58,3 \%$ das amostras da marca $\mathrm{B}_{1}, 50,0 \%$ da marca $B_{2}$ e $66,7 \%$ da marca $B_{3}$ não atenderam as especificações da DINAL (1987), para microrganismos mesófilos. As amostras das marcas $B_{1}, B_{2}$ e $B_{3}$ analisadas mostraram-se fora dos padrões DINAL (1987) em percentuais de 75,0\%, 75,0\% e $66,7 \%$, respectivamente, para coliformes totais; em relação à contaminação por coliformes fecais, amostras das marcas $\mathrm{B}_{1}$ e $\mathrm{B}_{2}$, apresentaram-se fora dos referidos padrões em percentuais de $16,7 \%$, em ambas as marcas.

Das quatro marcas analisadas do leite tipo $C$, observou-se que as marcas $\mathrm{C}_{1}(16,7 \%), \mathrm{C}_{2}(25,0 \%), \mathrm{C}_{3}(41,7 \%)$ e $\mathrm{C}_{4}(50,0 \%)$, apresentaram-se fora das especificações da DINAL (1987) para microrganismos mesófilos; a presença de coliformes totais foi constatada em níveis superiores aos permitidos pela legislação nacional, nas amostras das marcas $C_{1}(16,7 \%), C_{2}(83,3 \%), C_{3}(75,0 \%)$ e $C_{4}$ $(25,0 \%)$ e a presença de coliformes fecais também em desacordo com os padrões da DINAL (1987) foi observada nas marcas $C_{2}(25,0 \%)$ e $C_{3}(41,7 \%)$.

Pelos resultados obtidos concluiu-se que são insatisfatórias as condições microbiológicas do leite pasteurizado dos tipos $\mathrm{A}, \mathrm{B}$ e $\mathrm{C}$ das marcas analisadas, distribuído na cidade de Piracicaba, SP, evidenciando possíveis falhas na 
linha de processamento e distribuição do produto, sendo difícil afirmar no presente trabalho, em qual etapa ocorreram falhas, uma vez que só foram analisados os produtos finais, já nas prateleiras dos pontos de venda.

Estes dados representam um alerta aos órgãos da Inspeção Sanitária, no sentido de que um controle mais rigoroso deva ser exercido para evitar que um alimento de tão grande importância na alimentação da população em desenvolvimento, seja ofertado em más condições, sob o ponto de vista microbiológico. 


\title{
MICROBIOLOGICAL CONDITIONS EVALUATION OF PASTEURIZED
}

MILK TYPES A, B, AND C COMMERCIALIZED IN PIRACICABA, SP

\author{
Author: SUELY GOMES TAVARES \\ Adviser: Prof. Dr. CLAUDIO ROSA GALLO
}

\section{SUMMARY}

The microbiological conditions of pasteurized milk, of different brands, two from type A, three from type B, and four from type C, totaling 24 samples from type A, 36 from type B and 48 from type C were evaluated.

The collected milk samples marketed in Piracicaba,SP, from January to June, 1995, were analyzed for mesophilic, thermophilic, psychrophilic and/or psychrotrophic microbial presence, total and fecal coliforms, for comparison with the DINAL standards (1987) which maintain the quality control of commercial marketed product.

The results of the analysis showed that brands $A_{1}$ and $A_{2}$ pasteurized milk had respectively $66.7 \%$ and $75.0 \%$ samples out of those standards, for mesophilic microorganisms; the total coliforms at higher levels than those allowed by the DINAL standards was found in $33.3 \%$ and $25.0 \%$ from samples of $A_{1}$ and $A_{2}$, respectively; the fecal coliforms absence was observed in two brands analyzed. 
For type B milk, $58.3 \%$ of samples from $B_{1}, 50.0 \%$ of samples from $\mathrm{B}_{2}$, and $66.7 \%$ from $\mathrm{B}_{3}$ brand, these results failed to attend the DINAL specifications (1987), for mesophilic microorganisms. Samples analyzed from $B_{1}, B_{2}$, and $B_{3}$ brands, showed themselves out of the DINAL standards (1987) presenting percentuals of $75.0 \%, 75.0 \%$, and $66.7 \%$, respectively, for total coliforms; concerning fecal coliforms types $B_{1}$ and $B_{2}$ samples failed to meet those standards in percentals of $16.7 \%$ in both brands.

From the four analyzed brands of type $\mathrm{C}$ milk, it was observed that $\mathrm{C}_{1}(16.7 \%), \mathrm{C}_{2}(25.0 \%), \mathrm{C}_{3}(41.7 \%)$ and $\mathrm{C}_{4}(50.0 \%)$, showed themselves out the DINAL standard specifications (1987) for mesophilic microorganisms; the presence of total coliforms verified been at higher levels than those allowed by the national legislation, in samples of types $C_{1}(16.7 \%), C_{2}(83.3 \%), C_{3}(75.0 \%)$, and $C_{4}$ $(25.0 \%)$. It was observed the presence of fecal coliforms in types $C_{2}(25.0 \%)$ and $\mathrm{C}_{3}(41.7 \%)$, disaccording to the DINAL standards (1987).

The results indicated that the microbiological conditions of pasteurized milk types A, B, and C, marketed in Piracicaba, SP, are improper, so, there are failures in procedure and distribution way. It is difficult in this research to point out in which stage there were the failures occurrence, because the products were analyzed after their final stage. 


\section{INTRODUÇÃO}

O leite de vaca apresenta em sua composição os principais nutrientes necessários à manutenção e desenvolvimento do indivíduo. Portanto, constitui parte da dieta diária do ser humano, visto possuir excepcional valor nutritivo.

O valor nutricional do leite está baseado principalmente em seu perfeito balanço de nutrientes. Por outro lado, estas características o tornam um dos alimentos mais suscetíveis de sofrer alterações físico-químicas e deterioração por microrganismos oriundos de diferentes fontes.

Sendo o leite excelente meio de cultivo para a maioria dos microrganismos comumente encontrados na natureza, ele sofre alterações com grande facilidade em curto espaço de tempo.

Para que os valores calórico e nutritivo do leite sejam mantidos, se faz necessário produzí-lo, pasteurizá-lo e comercializá-lo em condições higiênicosanitárias satisfatórias que não permitam veicular patógenos, sem no entanto, alterar as características que lhe são próprias. O prolongamento da vida útil do produto é conseguido por manutenção do mesmo à temperatura inferior a $10^{\circ} \mathrm{C}$, até o momento do consumo. 
O leite e derivados podem, em determinadas condições transmitir ao homem, uma grande variedade de doenças. Em função disto, pode-se afirmar que a qualidade do leite e derivados está estreitamente relacionada com a sua produção e tecnologia. Por isso, é preciso haver vigilância constante, desde a ordenha do leite ou a obtenção do derivado, até o consumo do alimento.

Há evidências experimentais de que o número de bactérias e a atividade do crescimento bacteriano no leite dependem da manipulação, limpeza do equipamento, higiene dos operários, condições sanitárias das instalações e temperatura de armazenamento.

Os órgãos competentes, os produtores, preocupados em manter o leite pasteurizado em boas condições higiênico-sanitárias, conservando as características físico-químicas, desde a produção até o consumo, tem desenvolvido pesquisas visando manter melhores condições bacteriológicas e físico-químicas do leite pasteurizado.

As inúmeras provas de controle higiênico do leite realizadas nas diversas fases de sua obtenção e manipulação visam avaliar, controlar e reparar irregularidades do produto a ser oferecido ao consumo.

Do ponto de vista de saúde pública as investigações bacteriológicas e físico-químicas do leite tornam-se cada vez mais importantes, no sentido de fornecer subsídios às futuras pesquisas que objetivam auxiliar a melhoria de etapas da produção, do beneficiamento e da comercialização do produto. 
Sendo os microrganismos os principais responsáveis pela transmissão de doenças a partir do leite e derivados, os processos de conservação e tratamentos visam de maneira direta ou indireta, combater esses agentes.

A pasteurização seguida de refrigeração, são métodos bastante eficazes, quando bem monitorados. Embora o processo de pasteurização assegure a destruição de muitos microrganismos, vários fatores como: temperatura de armazenamento inadequada, má higienização de utensílios e equipamentos diversos utilizados no processamento e condições de sanidade dos manipuladores, propiciam condições favoráveis para a recontaminação do leite.

A matéria-prima é um fator importante na qualidade microbiológica do leite e derivados, pois se excessivamente contaminada, refletirá num produto de má qualidade. Portanto, a qualidade microbiológica do leite destinado ao consumo humano depende basicamente do controle de três fatores: extensão da contaminação da matéria-prima, eficiência da pasteurização e extensão da contaminação do produto final (condições de transporte e temperatura de armazenamento). No entanto, é praticamente impossível evitar de modo absoluto a contaminação do leite.

No Brasil, a má qualidade do leite está relacionada com o controle higiênico-sanitário deficiente, enquanto que nos países desenvolvidos, a má qualidade do leite é atribuída a casos de mastite bovina. Os microrganismos patogênicos Staphylococcus aureus, Streptococcus agalactiae, Streptococcus dysgalactiae, Streptococcus uberis, sempre presentes no úbere mastítico e o grande número de células somáticas presentes no leite reduzem acentuadamente a sua qualidade. 


\section{OBJETIVO}

O presente trabalho teve como objetivo fazer um levantamento das condições microbiológicas do leite pasteurizado comercializado em Piracicaba, SP, pesquisando-se coliformes totais e fecais e realizando-se contagem microbiana total de mesófilos, termófilos e psicrotróficos e/ou psicrófilos para comparação com os padrões vigentes no País. 


\section{REVISÃO BIBLIOGRÁFICA}

\subsection{Qualidade microbiológica do leite para consumo humano}

Tendo em vista a importância do leite sob os aspectos nutricionais, econômicos, sociais e de saúde pública, a qualidade desse produto tem merecido a atenção de inúmeros pesquisadores em todo o mundo. Sendo consumido por todas as faixas etárias, torna-se necessário que sua qualidade seja garantida (SPREER, 1975; FERREIRA, 1977; PANETTA, 1984).

A contaminação do leite é extremamente variável. A grandeza e a diversidade da população contaminante variam consideravelmente e estão intimamente associadas à origem do leite (PELCZAR et al., 1981; HARVEY \& HILL, 1989).

Nas glândulas mamárias do animal sadio, o leite é praticamente estéril; todavia, sua contaminação começa a ocorrer já nos próprios canais lactíferos e vai aumentando até sair das tetas (BARUFALDI et al., 1984).

Sob o ponto de vista tecnológico, os contaminantes mais importantes são aqueles que atingem o leite quando este entra em contato com o ordenhador, 
utensílios e equipamentos diversos utilizados na ordenha e manuseio do leite da fazenda até a usina ou indústria de laticínio (BARUFALDI et al., 1984).

Bactérias presentes no leite, podem causar infecções e intoxicações alimentares, bem como sua deterioraçåo, diminuindo assim a sua vida útil (OLIVEIRA, 1976).

As bactérias (Salmonella, Shigella, Staphylococcus, Clostridium e as do grupo coliforme), são microrganismos que provocam alterações no leite e que, de uma forma ou de outra, podem prejudicar a saúde do homem, através dos produtos de leite e seus derivados consumidos (CRUZ, 1984; VIEIRA et al., 1994).

Os métodos utilizados para a enumeração dos microrganismos patogênicos nos alimentos são geralmente caros e de difícil realização; por isso, a indústria utiliza certos grupos ou espécies de microrganismos, os quais podem ser mais facilmente enumerados e cuja presença nos alimentos indica exposição a certas condições, que favorecem a introdução de patogênicos nos alimentos. Este grupo é denominado de microrganismos indicadores, que há muito vem sendo utilizado para avaliar a qualidade higiênica dos alimentos (SPECK, 1984; NASCIMENTO et al., 1991).

\subsection{Microrganismos indicadores de contaminação fecal - coliformes}

O grupo de microrganismos coliformes é restrito ao trato gastrointestinal de humanos e animais homeotérmicos. Este grupo inclui bactérias aeróbias e 
anaeróbias facultativas, Gram-negativas, não esporogênicas, com capacidade de fermentar a lactose com produção de gás num período de 48 horas a $35^{\circ} \mathrm{C}$ (SPECK, 1984).

O grupo de microrganismos coliformes totais e fecais é considerado indicador das condições higiênicas da produção e beneficiamento do leite pasteurizado apresentando fácil quantificação laboratorial (SPECK, 1984). A utilização do grupo coliforme como indicador das condições higiênico-sanitárias em alimentos, é prática estabelecida há muitos anos. Dos agentes bacterianos, os coliformes são internacionalmente considerados microrganismos indicadores da segurança microbiológica de alimentos (BONASSI, 1984; SPECK, 1984; ROGICK, 1987; NASCIMENTO et al., 1991).

O grupo coliforme compreende os gêneros Escherichia, Citrobacter, Enterobacter e Klebsiella, segundo a nomenclatura do BERGEY'S Manual of Systematic Bacteriology, 1984.

Segundo ROGICK (1987), a bactéria coliforme fecal Escherichia coli, quando presente no alimento, é geralmente considerada como uma indicação de poluição de origem fecal direta ou indireta, evidenciando riscos da presença de patógenos entéricos como salmonelas, shigelas, víbrios, que podem ocorrer nas áreas de produção e processamento (KORNACKI \& MARTH, 1982). 


\subsection{Microrganismos Mesófilos, Termófilos e Psicrotróficos e/ou Psicrófilos}

Nas indústrias de laticínios brasileiras, onde há deficiências higiênicas, tanto no manuseio do leite como na limpeza dos utensílios e equipamentos, as contagens microbianas são, em geral, bastante altas. Consequentemente, o nosso leite tem apresentado baixa qualidade, com leite pasteurizado tendo uma conservação de 3 a 4 dias, que é cerca de 5 vezes menor do que em países mais desenvolvidos (OLIVEIRA, 1976).

Os mesófilos incluem grupo de microrganismos capazes de se multiplicarem numa faixa de temperatura entre 20 a $40^{\circ} \mathrm{C}$, tendo uma temperatura ótima de crescimento a $32^{\circ} \mathrm{C}$, e, portanto, encontrando nas temperaturas ambientes de países de clima tropical, condições ótimas para o seu metabolismo.

Esse grupo é muito importante, por incluir a maioria dos contaminantes do leite, tanto deterioradores como patógenos. É considerado também um bom indicador de qualidade microbiológica, sendo a contagem microbiana em placa realizada para se avaliar as condições higiências na qual o produto foi processado.

Contagens microbianas de mesófilos elevadas no leite pasteurizado, podem indicar uma matéria-prima excessivamente contaminada, manipulação inadequada, equipamentos da planta de processamento não adequadamente sanitizados e pasteurização deficiente (VIEIRA, 1976; ROGICK, 1987). 
Os termófilos incluem grupo de microrganismos capazes de se multiplicarem em temperaturas acima de $45^{\circ} \mathrm{C}$, sendo que $55^{\circ} \mathrm{C}$ é considerada a temperatura ótima. É relativamente pequena a importância desse grupo, uma vez que são poucas as ocasiões em que produtos de laticínios permanecem nesta faixa de temperatura por um período de tempo considerável, exceto no caso da fase de concentração do leite no processamento do leite evaporado e do leite em pó.

Geralmente microrganismos termófilos são encontrados em baixo número no leite pasteurizado, mas encontrando boas condições para multiplicação, podem atingir um número elevado. Estas bactérias são encontradas na silagem, no esterco e no solo, equipamentos e utensílios mal higienizados. Os principais gêneros são Bacillus e Clostridium, responsáveis pela degradação de proteínas, coagulação do leite e alterações organolépticas (REINBOLD, 1971; BARUFALDI et al., 1984; VESSONI-PENNA et al., 1986).

Os microrganismos psicrotróficos e/ou psicrófilos são capazes de crescer em condições de refrigeração, embora a maioria deles prefira como condições ótimas de multiplicação, temperaturas acima de $20^{\circ} \mathrm{C}$, e são capazes de formar colônias em ágar dentro de 10 dias de incubação a $7^{\circ} \mathrm{C}$. Esse grupo é extremamente importante em produtos que são conservados ou armazenados sob refrigeração por períodos relativamente longos ( 1 a 4 semanas), pois podem ocasionar alterações nos mesmos. Os microrganismos psicrotróficos e/ou psicrófilos, com poucas exceções, não sobrevivem a pasteurização. Dos sobreviventes, as bactérias Gram-negativas são 
raras, pois têm baixa resistência térmica. Por isso, muitos testes, usados para estimar a vida de prateleira do produto, utilizam a contagem de microrganismos psicrotróficos (LUCK et al., 1980; WHITE, 1982; TATINI et al., 1991).

\subsection{Pasteurização x Carga Microbiológica do Produto}

Comercialmente, são utilizados dois métodos de pasteurização: o método de manutenção a baixa temperatura e o método de alta temperatura. $\mathrm{O}$ método de pasteurização de manutenção em baixa temperatura expõe o leite a $62,8^{\circ} \mathrm{C}$ durante 30 minutos em equipamentos especialmente construidos. $\mathrm{O}$ processo de alta temperatura em curto tempo emprega instalações capazes de expor o leite a uma temperatura de $71,7^{\circ} \mathrm{C}$, pelo tempo de 15 segundos. Em qualquer um dos métodos de pasteurização empregado, é essencial que o produto final seja mantido a baixa temperatura, a fim de retardar o crescimento de germes sobreviventes (PELCZAR et al., 1981).

A finalidade da pasteurização é de destruir totalmente a flora microbiana patogênica e a quase totalidade dos microrganismos, sem alteração sensível da constituição física e do equilíbrio químico do leite e sem prejuízo de seus elementos bioquímicos, assim como de suas propriedades organolépticas normais; assegurando assim a qualidade de conservação do produto (GOMES, 1975; MARTH, 1985). 
O leite pasteurizado é descrito como um produto que reage negativamente ao teste de fosfatase e/ou positivamente ao teste de peroxidase (BOCKELMANN, 1976).

A fosfatase é uma enzima, presente no leite cru e em muitos tecidos, destruída por uma pasteurização adequada. Assim pode-se determinar se o leite foi suficientemente pasteurizado, testando a ausência desta enzima (BEHMER, 1991).

Análises microbiológicas do leite fornecem informações úteis que refletem as condições sob as quais o mesmo foi processado e armazenado. Altas contagens microbianas num alimento indicam matéria-prima contaminada, más condições sanitárias ou temperaturas impróprias de processamento e armazenamento (COSTA et al., 1983).

Os alimentos para serem considerados de boa qualidade sanitária, devem mostrar-se isentos de microrganismos prejudiciais, ou pelo menos tê-los em índices que possam ser considerados seguros (CRUZ, 1984).

Para assegurar a qualidade do alimento foram adotados padrões microbiológicos, que se baseiam na suposição de que os alimentos com números baixos de microrganismos apresentam menores possibilidades da presença de patogênicos (FRAZIER \& WESTHOFF, 1995).

Análises microbiológicas do leite cru foram realizadas por MOREIRA et al. (1971), em Santa Maria, RS; OLIVEIRA (1976) em Campinas, SP; TIBANA (1981) na cidade do Rio de Janeiro; JESSOUROUN (1983) na cidade de São Paulo 
e por VIEIRA et al. (1994) em algumas cidades mineiras, as quais mostraram a necessidade da pasteurização e serviram de alerta quanto a importância de boas condições higiênicas, ao detectarem a presença de microrganismos patogênicos como Salmonella spp., E. coli, S. aureus, Streptococcus agalactiae, S. faecalis, Yersinia enterocolitica, além da constatação de que mais de $50 \%$ das amostras analisadas estavam fora dos padrões legais para a contagem total de mesófilos.

CERQUEIRA-CAMPOS et al. (1983), pesquisaram grupos de bactérias no leite pasteurizado com teor de gordura de $3,2 \% \mathrm{~m} / \mathrm{v}$, e concluiram que apenas 8,3\% das amostras analisadas apresentavam-se fora do padrão nacional com relação as bactérias mesófilas.

VESSONI-PENNA et al. (1986), analisando as condições higiênicosanitárias do leite pasteurizado na cidade de São Paulo, constataram a presença de E. coli em $75,9 \%$ das amostras analisadas; em $17 \%$ das amostras analisadas foram encontrados valores de mesófilos acima dos permitidos pelo padrão nacional.

Certas bactérias patogênicas como Clostridium botulinum e $C$. perfringens são resistentes às temperaturas de pasteurização comercial e já foram isoladas tanto do leite cru como do leite pasteurizado (VIEIRA, 1976).

VESSONI-PENNA et al. (1986), realizaram a prova da redutase em leite pasteurizado, para avaliação de suas condições higiênico-sanitárias e constataram tempos de descoramento menores que $2: 30$ horas em $16,7 \%$ do total de amostras analisadas. 
A prova da redutase, que se baseia na velocidade de redução de corantes oxi-redutores pela enzima redutase, produzida por bactérias, geralmente, é realizada no leite "in natura" (SIPA,1980). Portanto quando aplicada ao leite pasteurizado, pode evidenciar uma sub-pasteurização ou contaminação pós beneficiamento (JESSOUROUN, 1983).

BALLOD \& BRAMORSKY (1990), analisaram 80 amostras de leite pasteurizado tipo $\mathrm{C}$, comercializado em Blumenau, $\mathrm{SC}$. Os resultados obtidos, para coliformes totais e fecais, mostraram que, $50 \%$ das amostras analisadas apresentaram-se com valores fora dos padrões da Divisão Nacional de Vigilância Sanitária de Alimentos (DINAL, 1987).

A presença de indicadores de contaminação fecal, além de dar uma idéia quanto ao aspecto higiênico-sanitário do referido produto, apresenta risco, tanto pela possibilidade da presença de outros enteropatógenos, como pela importância de algumas linhagens de E. coli serem patógenos entéricos potenciais (KORNACKI \& MARTH, 1982).

Pesquisas realizadas por BARUFALDI et al. no período de fevereiro a agosto de 1982 , constataram a presença de $E$. coli em $75,9 \%$ das amostras analisadas de leite pasteurizado tipo $\mathrm{B}$; na mesma pesquisa verificou-se que $65 \%$ das amostras analisadas apresentavam contagens microbianas superiores a $4,0 \times 10^{4}$ mesófilos $/ \mathrm{ml}$ de amostra. 
Numa pesquisa realizada por NASCIMENTO et al. (1991), para avaliar as condições microbiológicas do leite pasteurizado dos tipos $\mathrm{B}$ e C, comercializados na cidade de Piracicaba, SP, ficou evidente que as mesmas não eram satisfatórias. O leite tipo B, apresentou-se fora dos padrões nacionais vigentes, em $40 \%$ das amostras analisadas, enquanto que $16,7 \%$ das amostras de leite tipo $C$ apresentaramse fora dos referidos padrões para contagem total de mesófilos. Neste mesmo trabalho, a pesquisa de coliformes totais e fecais, realizada pelo método do número mais provável (NMP), revelou que 73,3\% das 30 amostras do leite tipo B analisadas estavam contaminadas com coliformes das quais $70 \%$ por coliformes fecais. Segundo os mesmos autores, a quantidade e a qualidade dos microrganismos encontrados, refletiu uma matéria-prima excessivamente contaminada, sub-pasteurizada, contaminada pós-processamento ou exposição do produto beneficiado a temperatura inadequada para sua conservação, porém não foi possível identificar em qual das etapas citadas ocorreu a falha.

TIBANA (1981), analisando amostras de leite pasteurizado tipo C, verificou que $58,3 \%$ das amostras analisadas apresentavam níveis superiores ao limite estabelecido pelo Ministério da Saúde, com relação a coliformes.

Análises microbiológicas do leite pasteurizado tipo $\mathrm{B}$, realizadas por RODRIGUES et al. (1993), revelaram que $76,4 \%$ das amostras analisadas estavam fora dos padrões nacionais para coliformes totais e $52,94 \%$ fora dos padrões para coliformes fecais. 
Pesquisas realizadas por THIELMANN et al. (1993), para avaliação da qualidade microbiológica de leite pasteurizado tipo A, constataram que o produto se encontrava dentro dos padrões microbiológicos da DINAL/Ministério da Saúde (1987).

SILVEIRA et al. (1988), em sua pesquisa, avaliaram as condições higiênico-sanitárias do leite pasteurizado tipos $\mathrm{A}, \mathrm{B}, \mathrm{C}$, oferecidos no comércio de São Paulo. Comparando os resultados obtidos com os padrões estabelecidos pela legislação vigente, verificaram que das 51 amostras do leite tipo A, das 84 amostras do tipo B e das 72 do tipo C, $42(82,35 \%) ; 31(36,90 \%)$ e $17(23,61 \%)$ respectivamente, estavam fora dos padrões estabelecidos pela legislação em vigor do Ministério da Saúde (DINAL, 1987).

NADER-FILHO et al. (1988), pesquisaram coliformes totais e coliformes fecais em 80 amostras de leite pasteurizado tipo B, coletadas na saída do pasteurizador, tendo todas elas se enquadrado nos padrões nacionais regulamentares. Todavia, $65 \%$ das amostras obtidas na saída do envase, mostraram-se fora dos padrões legais para o leite tipo B. Este fato, sugere a possibilidade de falhas de higienização dos equipamentos que entram em contato com o leite.

OLIVEIRA et al. (1994), vieram, através de sua pesquisa, reforçar a importância do tratamento térmico do leite, quando avaliaram o efeito do binômio tempo e temperatura na redução da carga microbiana do leite cru a nível de pequeno 
produtor, testando a eficiência do tratamento térmico em leite acondicionado em filme plástico, por vários períodos de tempo, em banho-maria. Esses autores, concluíram que o aquecimento do leite a $70^{\circ} \mathrm{C}$ por 20 minutos foi suficiente para reduzir a carga microbiana correspondente a uma boa pasteurização, mas dada a grande variação da população microbiana do leite, tanto em número quanto em espécie, para maior segurança, recomendam o aquecimento a $70^{\circ} \mathrm{C}$ por 25 minutos.

Com o propósito de obter-se um produto livre de contaminantes, o leite deve ser submetido ao tratamento térmico de pasteurização, seguido de refrigeração. Entretanto vários estudos têm evidenciado a presença de elevada carga microbiana no leite pasteurizado (LUCK, 1972; NASCIMENTO et al., 1991).

OLIVEIRA (1976) e LEDFORD et al. (1983) atribuíram a importância do grupo coliforme em produtos processados, não só como indicador de contaminação fecal pós-processamento do leite e derivados, mas também como responsáveis por inúmeros problemas de sabor, aroma e produção de gás.

A contagem de coliformes, é o método mais freqüentemente usado para se determinar contaminação pós-pasteurização (HANKIN et al., 1980), pois, como os coliformes normalmente são destruídos pela pasteurização, sua presença em leite pasteurizado indica, segundo BLANKENAGEL (1976), que ocorreu a contaminação pós-pasteurização. 
O leite pasteurizado, apesar de ser submetido a tratamento térmico, continua sendo um meio adequado para o desenvolvimento de microrganismos, pois a pasteurização garante a destruição das células vegetativas patogênicas, porém, permite a sobrevivência de outros microrganismos. Segundo GRIFFITHS \& PHILLIPS (1988), os tipos de microrganismos presentes no leite pasteurizado variam de acordo com a temperatura de armazenamento e a população microbiana inicial da matériaprima. O uso inadequado da combinação tempo-temperatura utilizada na pasteurização tem como conseqüência permitir a sobrevivência de microrganismos indesejáveis.

\subsection{Fatores que interferem na qualidade higiênica do leite}

Segundo ROGICK (1987) e PANETTA (1993), teoricamente a proteção da qualidade do leite repousa em medidas simples. Tais medidas podem ser assim resumidas: produção higiênica em granjas ou local de ordenha, situadas nas zonas rurais; resfriamento ou transporte rápido às centrais de beneficiamento; pasteurização e envase nos centros de beneficiamento; armazenamento adequado a nível de varejo.

As análises microbiológicas e físico-químicas devem sofrer permanente revisão para que possam atingir plenamente sua finalidade de conferir segurança ao público consumidor (REINBOLD, 1971). 
Grande parte dos problemas que envolvem a higiene do leite está relacionada com toda certeza, com as formas de produção, distribuição e comercialização do produto (REINBOLD, 1971; PANETTA, 1993).

\subsection{Classificação do leite de consumo}

\section{- Leite tipo A}

O leite tipo "A" ou de granja é assim denominado por ser resfriado, pasteurizado e envasado para consumo no local onde é produzido. Este tipo de leite deve ser produzido e beneficiado sob as mais rigorosas condições higiênicosanitárias.

O padrão sanitário desse tipo de leite é bem mais rigoroso, que para os demais uma vez que ele não passa por nenhuma intervenção manual (CARRIÓN, 1994).

\section{- Leite tipo B}

O leite tipo B obedece as mesmas exigências sanitárias de obtenção e de manejo de rebanho para o leite tipo A. A diferença é que o leite B pode ser transportado para um posto de refrigeração. Depois é levado para um entreposto 
maior, onde termina o beneficiamento. É um leite integral igual ao leite $\mathrm{A}$, onde não existe remoção de gordura.

\section{- Leite tipo C}

$\mathrm{O}$ leite $\mathrm{C}$ tem um padrão de manejo menos rigoroso no aspecto microbiológico e físico-químico. É permitida a ordenha manual e não é necessário ter no estábulo um inspetor no local, ficando o controle a cargo de um veterinário da Casa da Agricultura ou particular, o que não acontece com os leites do tipo $\mathrm{A}$ e $\mathrm{B}$, que não podem ser produzidos sem o controle da Secretaria de Inspeção Federal (SIF). No leite tipo C ocorre extração de gordura, procurando a padronização deste tipo de leite com 3,2\% de gordura (CARRIÓN, 1994).

\subsection{Padrões microbiológicos}

A Portaria 1/87 do Ministério da Saúde (DINAL, 1987) e o Ministério da Agricultura - Secretaria de Inspeção de Produto de Origem Animal (SIPA, 1994), estabelecem o seguintes padrões para o leite pasteurizado tipo A, que podem ser visualizados no Quadro 1. Os padrões para o leite pasteurizado tipos B e C, encontram-se nos Quadros 2 e 3, respectivamente. 
Quadro 1 - Padrões microbiológicos para leite pasteurizado tipo "A".

\begin{tabular}{|c|c|c|}
\hline \multirow{2}{*}{ MICRORGANISMOS } & \multicolumn{2}{|c|}{ Ministério da } \\
\hline & Agricultura ${ }^{1}$ & Saúde ${ }^{2}$ \\
\hline Contagem padrão de Mesófilos em placas (UFC/ml) & $5,0 \times 10^{2}$ & $2,0 \times 10^{3}$ \\
\hline Psicrotróficos (UFC/ml) & $5,0 \times 10^{1}$ & - \\
\hline Termófilos (UFC/ml) & $5,0 \times 10^{1}$ & - \\
\hline Coliformes Totais (NMP/ml) & ausência & 1 \\
\hline Salmonella (em $25 \mathrm{ml})$ & ausência & ausência \\
\hline
\end{tabular}

${ }^{1}$ Fonte: SIPA - (MINISTÉRIO DA AGRICULTURA, 1994)

${ }^{2}$ Fonte: DINAL - (MINISTÉRIO DA SAÚDE, 1987) 
Quadro 2 - Padrões microbiológicos para o leite pasteurizado tipo B.

\begin{tabular}{lcc}
\hline \hline & \multicolumn{2}{c}{ Ministério da } \\
\cline { 2 - 3 } \multicolumn{1}{c}{ MICRORGANISMOS } & Agricultura $^{1}$ & Saúde $^{2}$ \\
\hline Cantagem padrão de Mesófilos em placas (UFC/ml) & $4,0 \times 10^{4}$ & $8,0 \times 10^{4}$ \\
Psicrotróficos (UFC/ml) & $4,0 \times 10^{3}$ & - \\
Termófilos (UFC/ml) & $4,0 \times 10^{3}$ & - \\
Coliformes Totais (NMP/ml) & 2 & 4 \\
Coliformes Fecais (NMP/ml) & ausência & 1 \\
Salmonella (em 25 ml) & ausência & ausência \\
\hline \hline
\end{tabular}

Fonte: ' SIPA - MINISTÉRIO DA AGRICULTURA (1994)

2 DINAL - MINISTÉRIO DA SAÚDE (1987)

Quadro 3 - Padrão microbiológico para leite pasteurizado tipo C.

\begin{tabular}{lcc}
\hline \hline & \multicolumn{2}{c}{ Ministério da } \\
\cline { 2 - 3 } \multicolumn{1}{c}{ MICRORGANISMOS } & Agricultura $^{1}$ & Saúde $^{2}$ \\
\hline Cantagem padrão de Mesófilos em placas (UFC/ml) & $5,0 \times 10^{4}$ & $3,0 \times 10^{5}$ \\
Psicrotróficos (UFC/ml) & $5,0 \times 10^{3}$ & - \\
Termófilos (UFC/ml) & $5,0 \times 10^{3}$ & - \\
Coliformes Totais (NMP/ml) & 5 & 10 \\
Coliformes Fecais (NMP/ml) & ausência & 2 \\
Salmonella $(\mathrm{em} 25 \mathrm{ml})$ & ausência & ausência \\
\hline \hline
\end{tabular}

Fonte: ${ }^{1}$ SIPA - MINISTÉRIO DA AGRICULTURA (1994)

${ }^{2}$ DINAL - MINISTÉRIO DA SAÚDE (1987)

Nos Estados Unidos, a Organização de Saúde Pública estabelece, para leite pasteurizado tipo $\mathrm{A}$, uma contagem padrão em placas que não exceda a $3,0 \mathrm{x}$ 
$10^{4} \mathrm{UFC} / \mathrm{ml}$ e um NMP de coliformes totais que não exceda a $10 / \mathrm{ml}$ (Nelson \& Trout, $1951^{1}$ e Wilster, $1965^{2}$, citados por THIELMANN, 1995).

A legislação da Alemanha, segundo $\mathrm{Hahn}^{3}$ (1987), citado por THIELMANN (1995) adotou, a partir de 1989, como padrão para o leite tipo A ou I de melhor qualidade, o limite de $3,0 \times 10^{4} \mathrm{UFC} / \mathrm{ml}$ para contagem padrão, e menor que $1 / \mathrm{ml}$, para coliformes totais.

O padrão Suíço, para o leite classe I, é de menos que $8,0 \times 10^{4}$ UFC/ml, para contagem padrão (HOSTETTLER et al., 1978) e o Francês, menos que $3,0 \times 10^{4} \mathrm{UFC} / \mathrm{ml}$ para contagem padrão em placas e menos que $1 / \mathrm{ml}$, para o número de coliformes totais, citado por THIELMANN (1995).

A legislação Sul Africana não especifica padrão máximo para contagem total de bactérias, mas, no momento, um máximo de $3, \mathrm{O} \times 10^{4} \mathrm{UFC} / \mathrm{ml}$, é aceito.

Na Europa, a partir de janeiro de 1994, o leite para consumo deve conter até $10^{5}$ bactérias totais por mililitro (BRITO, 1995).

\footnotetext{
' NELSON, J.A.; TROUT, G.M. Judging dairy products. 3.ed. Wisconsin, The Olsen Publishing Milwaukee, 1951. 480p. In: THIELMANN, C. Avaliação das características da qualidade e prazo de validade do leite tipo "A". Viçosa, 1995. 127p. (Master Scientia - Universidade Federal de Viçosa).

2 WILSTER, G.H. Dairy testing and standards. 6.ed. Oregon, O.S.U. Book Stores, 1965. 312p. In: THIELMANN, C. Avaliação das características da qualidade e prazo de validade do leite tipo "A". Viçosa, 1995. 127p. (Master Scientia - Universidade Federal de Viçosa).

${ }^{3}$ HAHN, H. Embodiment of the EEC milk hygiene direstive in natural law. Deutche Molkereizeitung, 108(46):1494-5, 1987. In: THIELMANN, C. Avaliação das características da qualidade e prazo de validade do leite tipo "A". Viçosa, 1995. 127p. (Master Scientia - Universidade Federal de Viçosa).
} 


\section{MATERIAL E MÉTODOS}

\section{- Amostras}

Leite bovino pasteurizado $(1000 \mathrm{ml})$, tipos $\mathrm{A}, \mathrm{B}$ e $\mathrm{C}$ de várias marcas comercializadas em Piracicaba, SP.

- Meios de cultivo

. CVBLB 2\% (Brilliant green Bile 2\% - DIFCO 0007-01-2)

. PCA (Plate Count Agar - DIFCO 0479-01-1)

\section{- Equipamentos}

. Balança Digital B 600

. Estufa incubadora

. Estufa de esterilização

. Autoclave

. Contador de colônias

. Banho-Maria 


\section{- Outros}

. Equipamentos e vidrarias de uso corrente em microbiologia.

. Solução Tampão Fosfato de Butterfields (SPECK, 1984)

. Solução de Azul de Metileno para prova de redutase (BEHMER, 1991)

\section{- Obtenção das amostras}

As amostras de leite pasteurizado tipos $\mathrm{A}, \mathrm{B}$ e $\mathrm{C}$, foram adquiridas no comércio de Piracicaba, SP, tendo sido coletadas quinzenalmente, durante o período de Janeiro a Junho/1995.

As amostras de leite, de marcas diferentes, sendo duas do tipo A, três do tipo $\mathrm{B}$ e quatro do tipo $\mathrm{C}$, foram transportadas nas embalagens originais, em isopor, imediatamente para o Laboratório de Microbiologia de Alimentos do Departamento de Ciência e Tecnologia Agroindustrial da Escola Superior de Agricultura "Luiz de Queiroz", afim de proceder as análises.

As 12 coletas foram efetuadas em pontos de venda, de pequeno, médio e grande porte, procurando alterná-los a cada 4 coletas, tendo assim, para cada tipo de leite, diferentes pontos de comercialização, tanto pertencentes a uma mesma categoria quanto ao porte, bem como diferentes portes de estabelecimentos. 
Foram analisadas 24 amostras de leite pasteurizado tipo A, 36 amostras de leite pasteurizado tipo B e 48 amostras de leite pasteurizado tipo $\mathrm{C}$, totalizando assim 108 amostras.

\section{- Preparo das amostras}

As amostras de leite pasteurizado foram analisadas de acordo com as especificações da Associação Brasileira de Normas Técnicas (ABNT, 1991).

No laboratório as amostras de leite pasteurizado foram homogeneizadas nas próprias embalagens. As embalagens foram desinfetadas externamente com álcool e alíquotas de $10 \mathrm{ml}$ de cada amostra de leite pasteurizado, foram tomadas para proceder diluições em série até $10^{-5}$, para posterior plaqueamento em profundidade em PCA.

Alíquotas de $10 \mathrm{ml}$ e de $1 \mathrm{ml}$ da diluição $10^{-1}$ e de $1 \mathrm{ml}$ da diluição $10^{-2}$, foram transferidas para 3 séries de 3 tubos contendo caldo verde brilhante bile $2 \%$, os quais foram incubados por 48 horas a $32^{\circ} \mathrm{C}$, para detectar a presença ou não de coliformes totais.

Após a incubação dos mesmos, foram observados tubos que apresentaram produção de gás, dos quais, com o auxílio de alça níquel-cromo foram retiradas alíquotas e transferidas novamente para CVBLB $2 \%$ e incubados por 24 horas a $44,5^{\circ} \mathrm{C}$ em banho-maria, para detecção de coliformes fecais. 
De cada diluição, foram retiradas alíquotas de $1 \mathrm{ml}$ para proceder o plaqueamento em PCA, para a contagem total de microrganismos (mesófilos, termófilos e psicrotróficos e/ou psicrófilos), com incubação a $32^{\circ} \mathrm{C} / 48 \mathrm{~h}, 55^{\circ} \mathrm{C} / 48$ h e $7^{\circ} \mathrm{C} / 10$ dias, respectivamente.

A Figura 1, ilustra todo procedimento adotado na realização das análises. As determinações dos números desses microrganismos, foram realizadas segundo as recomendações da American Public Health Association (SPECK, 1984). Os resultados obtidos foram comparados com os padrões vigentes no País. 


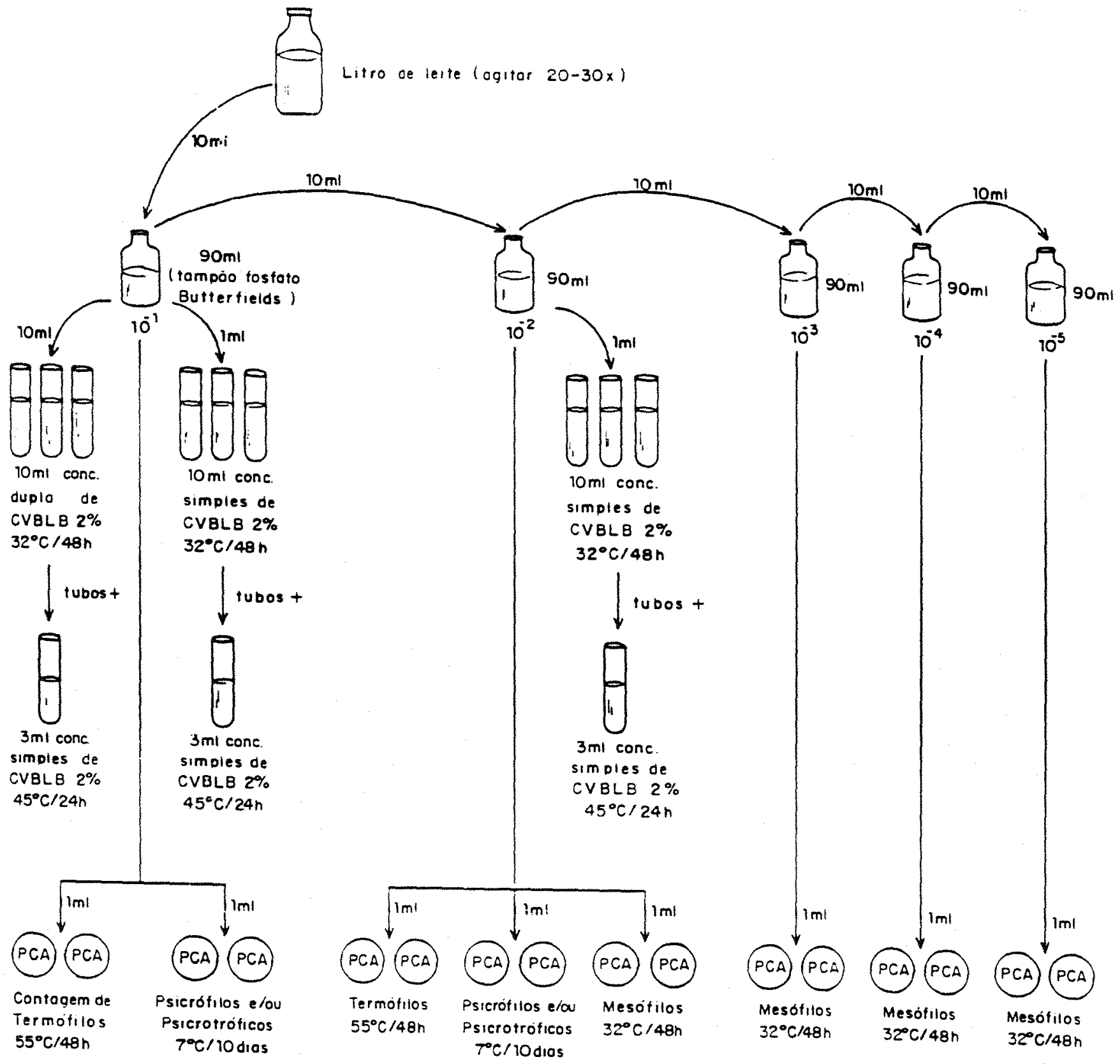

Figura 1 - Esquema do procedimento analítico. 


\section{RESULTADOS E DISCUSSÃO}

A Tabela 1 apresenta os dados referentes aos percentuais de amostras que se encontraram fora dos padrões microbiológicos estipulados pela Portaria 1/87 da DINAL e pela SIPA (1994).

A DINAL é um órgão do Ministério da Saúde, que fiscaliza o produto no comércio varejista, enquanto a SIPA, um órgão do Ministério da Agricultura, que fiscaliza o produto ainda na indústria.

Os resultados das análises microbiológicas do leite pasteurizado tipo A, são apresentados na Tabela 2, com contagens totais em placas de mesófilos, termófilos, psicrófilos e/ou psicrotróficos e na Tabela 3, com o NMP de coliformes totais e fecais.

Os dados obtidos nesta pesquisa (Tabela 2) mostram que a variação encontrada para mesófilos foi de $8,5 \times 10$ a $3,7 \times 10^{5} \mathrm{UFC} / \mathrm{ml}$ para o leite tipo A; onde para a marca $A_{1}$, a variação encontrada foi de $8,5 \times 10$ a $3,0 \times 10^{5} \mathrm{UFC} / \mathrm{ml}$ e para a marca $\mathrm{A}_{2}$ foi de $6,5 \times 10^{2}$ a $3,7 \times 10^{5} \mathrm{UFC} / \mathrm{ml}$; para microrganismos termófilos a variação encontrada foi de $2,0 \times 10$ a $3,8 \times 10^{3} \mathrm{UFC} / \mathrm{ml}$, sendo para a 
marca $A_{1}$ de $2,5 \times 10$ a $3,8 \times 10^{3} \mathrm{UFC} / \mathrm{ml}$, e para a marca $A_{2}$ de $2,0 \times 10$ a 2,1 x $10^{3} \mathrm{UFC} / \mathrm{ml}$; para microrganismos psicrófilos e/ou psicrotróficos a variação encontrada foi de $1,1 \times 10^{2}$ a $5,9 \times 10^{3} \mathrm{UFC} / \mathrm{ml}$, sendo para a marca $A_{1}$ de $1,2 \times 10^{2}$ a $5,8 \times 10^{3} \mathrm{UFC} / \mathrm{ml} \mathrm{e}$, para a marca $\mathrm{A}_{2}$ uma variação de $1,1 \times 10^{2}$ a $5,9 \times 10^{3}$ $\mathrm{UFC} / \mathrm{ml}$. Dessa forma, para a marca $\mathrm{A}_{1}, 91,7 \%$ das amostras analisadas estiveram com contagens de mesófilos acima dos padrões estabelecidos pela SIPA (1994) e $66,7 \%$ das mesmas estiveram com contagens de mesófilos acima dos padrões da DINAL (1987). Para a marca $A_{2}, 100$ e $75,0 \%$ das amostras apresentaram-se, respectivamente, fora dos padrões SIPA (1994) e DINAL (1987), conforme mostrado na Figura 2-A.

A Secretaria de Inspeção de Produto Animal (SIPA, 1994), determina uma contagem total de mesófilos máxima de 5,0 x 10² UFC/ml e a DINAL (1987), estabelece como máximo de mesófilos $2,0 \times 10^{3} \mathrm{UFC} / \mathrm{ml}$. Os dados da Tabela 2 mostram que as amostras de número $2,3,4,6,7,8,10$ e 12 da marca $A_{1}$ e 1, 2, $3,4,5,8,9,10$ e 12 da marca $A_{2}$ apresentaram contagens superiores aos padrões menos rigorosos, ou seja, da DINAL (1987). 
Tabela 1 - Porcentagens de amostras de leite pasteurizado tipos A, B e C, fora dos padrões, segundo as portarias 1/87 do Ministério da Saúde-DINAL e 8/94 do Ministério da Agricultura-SIPA.

\begin{tabular}{|c|c|c|c|c|c|c|c|c|c|c|c|}
\hline \multirow[b]{3}{*}{ Tipo } & \multirow[b]{3}{*}{ Marca } & \multirow{2}{*}{\multicolumn{2}{|c|}{ Mesófilos }} & \multirow{2}{*}{\multicolumn{2}{|c|}{ Termótilos }} & \multirow{2}{*}{\multicolumn{2}{|c|}{$\begin{array}{l}\text { Psicrotróficos } \\
\text { e/ou Psicrófilos }\end{array}$}} & \multicolumn{4}{|c|}{ Coliformes } \\
\hline & & & & & & & & \multicolumn{2}{|c|}{ Totais } & \multicolumn{2}{|c|}{ Fecais } \\
\hline & & DINAL & SIPA & DINAL & SIPA & DINAL & SIPA & DINAL & SIPA & DINAL & SIPA \\
\hline & Al & 66,7 & 91,7 & -. & 83,3 & -. & 100,0 & 33,3 & 50,0 & 0 & 0 \\
\hline \multirow[t]{2}{*}{ A } & $\mathrm{A} 2$ & 75,0 & 100,0 & -- & 83,3 & -- & 100,0 & 25,0 & 50,0 & 0 & 0 \\
\hline & B1 & 58,3 & 75,0 & - & 0 & -- & 58,3 & 75,0 & 83,3 & 16,7 & 25,0 \\
\hline \multirow[t]{4}{*}{ B } & $\mathrm{B} 2$ & 50,0 & 83,3 & -- & 25,0 & -- & 16,7 & 75,0 & 91,7 & 16,7 & 58,3 \\
\hline & B3 & 66,7 & 83,3 & -- & 0 & -. & 58,3 & 66,7 & 83,3 & 0 & 0 \\
\hline & $\mathrm{Cl}$ & 16,7 & 50,0 & $\cdots$ & 0 & - & 50,0 & 16,7 & 16,7 & 0 & 0 \\
\hline & $\mathrm{C} 2$ & 25,0 & 83,3 & -- & 25,0 & -- & 66,7 & 83,3 & 100,0 & 25,0 & 58,3 \\
\hline \multicolumn{12}{|l|}{$\mathrm{C}$} \\
\hline & $\mathrm{C} 3$ & 41,7 & 91,7 & -- & 16,7 & - & 75,0 & 75,0 & 83,3 & 41,7 & 50,0 \\
\hline & $\mathrm{C} 4$ & 50,0 & 100,0 & -. & 16,7 & -. & 58,3 & 25,0 & 33,3 & 0 & 8,3 \\
\hline
\end{tabular}

-- Padrão não especificado 
Tabela 2 - Unidades Formadoras de Colônias (UFC/ml) de microrganismos mesófilos, termófilos e psicrófilos e/ou psicrotróficos nas 24 amostras de leite pasteurizado tipo A.

\begin{tabular}{|c|c|c|c|c|c|c|}
\hline \multicolumn{4}{|c|}{$\mathrm{A}_{1}$} & \multicolumn{3}{|c|}{$\mathrm{A}_{2}$} \\
\hline \multicolumn{2}{|c|}{ Mesófilos } & \multirow{2}{*}{$\begin{array}{l}\text { Termófilos } \\
\text { UFC/ml }\end{array}$} & \multirow{2}{*}{$\begin{array}{l}\text { Psicrófilos e/ou } \\
\text { Psicrotróficos }\end{array}$} & \multirow[t]{2}{*}{ Mesófilos } & \multirow{2}{*}{$\begin{array}{l}\text { Termófilos } \\
\text { UFC/ml }\end{array}$} & \multirow{2}{*}{$\begin{array}{l}\text { Psicrófilos e/ou } \\
\text { Psicrotróficos }\end{array}$} \\
\hline & & & & & & \\
\hline 1 & $8,5 \times 10$ & $1,1 \times 10^{3}$ & $1,7 \times 10^{3}$ & $3,7 \times 10^{5}$ & $1,8 \times 10^{3}$ & $4,0 \times 10^{2}$ \\
\hline 2 & $2,6 \times 10^{4}$ & $2,5 \times 10$ & $4,5 \times 10^{3}$ & $3,7 \times 10^{3}$ & $1,8 \times 10^{3}$ & $5,7 \times 10^{3}$ \\
\hline 3 & $5,7 \times 10^{4}$ & $1,7 \times 10^{2}$ & $1,4 \times 10^{2}$ & $4,8 \times 10^{4}$ & $8,0 \times 10$ & $2,2 \times 10^{2}$ \\
\hline 4 & $3,0 \times 10^{5}$ & $3,8 \times 10^{3}$ & $5,8 \times 10^{3}$ & $3,0 \times 10^{3}$ & $2,1 \times 10^{3}$ & $5,8 \times 10^{3}$ \\
\hline 5 & $2,0 \times 10^{3}$ & $3,4 \times 10^{3}$ & $5,2 \times 10^{3}$ & $3,0 \times 10^{5}$ & $1,7 \times 10^{3}$ & $1,0 \times 10^{3}$ \\
\hline 6 & $1,6 \times 10^{5}$ & $2,5 \times 10$ & $9,8 \times 10^{2}$ & $6,5 \times 10^{2}$ & $2,0 \times 10$ & $2,1 \times 10^{2}$ \\
\hline 7 & $3,0 \times 10^{3}$ & $1,6 \times 10^{2}$ & $1,4 \times 10^{2}$ & $1,2 \times 10^{7}$ & $1,3 \times 10^{2}$ & $4,4 \times 10^{2}$ \\
\hline 8 & $2,5 \times 10^{3}$ & $1,1 \times 10^{2}$ & $1,3 \times 10^{3}$ & $1,5 \times 10^{4}$ & $7,5 \times 10$ & $1,1 \times 10^{3}$ \\
\hline 9 & $1,7 \times 10^{3}$ & $8,0 \times 10$ & $1,2 \times 10^{2}$ & $3,2 \times 10^{3}$ & $2,0 \times 10$ & $1,1 \times 10^{2}$ \\
\hline 10 & $4,8 \times 10^{3}$ & $1,1 \times 10^{3}$ & $1,7 \times 10^{3}$ & $2,7 \times 10^{3}$ & $9,0 \times 10^{2}$ & $3,9 \times 10^{3}$ \\
\hline 11 & $1,5 \times 10^{3}$ & $1,1 \times 10^{3}$ & $9,5 \times 10^{2}$ & $1,3 \times 10^{3}$ & $1,7 \times 10^{3}$ & $1,0 \times 10^{3}$ \\
\hline 12 & $5,7 \times 10^{4}$ & $3,4 \times 10^{3}$ & $4,5 \times 10^{3}$ & $4,0 \times 10^{3}$ & $1,8 \times 10^{3}$ & $5,9 \times 10^{3}$ \\
\hline
\end{tabular}

Em muitos países a qualidade higiênica do leite é avaliada pelo controle microbiológico, por meio da contagem total de microrganismos (bactérias, leveduras 
e fungos filamentosos) e da contagem de células somáticas, esta última devido a muitos casos de mastite bovina que representa constante possibilidade de veiculação de microrganismos patogênicos ou suas toxinas, como $S$. aureus, bactéria predominante nos casos de mastite (NADER FILHO et al., 1988; BRITO, 1995).

A contagem total em placas é feita a uma temperatura de $32^{\circ} \mathrm{C}$, o que favorece o crescimento de microrganismos mesófilos, consequentemente de patógenos. Segundo VIEIRA (1976) produtos que possuem uma contagem de $10^{6} \mathrm{a}$ $10^{8}$ microrganismos por mililitro, apresentam sinais de deterioração. Embora em nenhuma amostra analisada tenha sido verificada uma contagem total de mesófilos acima de $10^{6} \mathrm{UFC} / \mathrm{ml}$, várias amostras analisadas das marcas $A_{1}$ e $A_{2}$, podem ser consideradas como produtos de baixa qualidade, de acordo com a DINAL (1987) e a SIPA (1994).

Segundo LUCK (1972), SAMAGH \& CUNNINGHAM, 1972, OLSON et al. (1980), SCHRODER et al. (1982), TERNSTRÖM et al. (1993) e BRITO (1995), a vida útil do leite pasteurizado depende, fundamentalmente, da carga microbiana inicial. Embora a contagem total de mesófilos seja considerada um bom indicador da qualidade microbiológica, sabe-se que a microbiota psicrófila e/ou psicrotrófica, composta principalmente por Pseudomonas e outras bactérias Gramnegativas não fermentativas, é a principal responsável pela deterioração do produto armazenado sob refrigeração e o problema torna-se ainda mais sério quando se 
considera que o uso intensivo da refrigeração, desde a fazenda até a residência do consumidor, pode provocar uma gradativa seleção para esse grupo de microrganismos. Esses mesmos autores, citam que a presença de bactérias psicrófilas e/ou psicrotróficas em leite pasteurizado, sugere contaminação pós-pasteurização ou pasteurização inadequada.

SCHRODER et al. (1982), relataram que o Institute of Food Science and Technology recomenda para conservação do leite pasteurizado, temperaturas variando de 0 a $5^{\circ} \mathrm{C}$. Sendo assim, o produto poderá manter-se por uma semana em boas condições de consumo, mesmo com uma contagem de psicrófilos e/ou psicrotróficos de $10^{3} \mathrm{UFC} / \mathrm{ml}$ de leite.

A Secretaria de Inspeção de Produto Animal - SIPA (1994), estabelece uma contagem de psicrotróficos máxima de 5,0 × $10 \mathrm{UFC} / \mathrm{ml}$ de leite pasteurizado tipo A. Tanto a marca $\mathrm{A}_{1}$ como a $\mathrm{A}_{2}$, apresentaram $100 \%$ de suas amostras, fora do referido padrão (Figura 2-C), porém todas as amostras de leite tipo A analisadas apresentaram uma contagem máxima de $10^{3}$ psicrófilos e/ou psicrotróficos por mililitro, que segundo SCHRODER et al. (1982), as colocam como produtos em boas condições de consumo, se armazenados entre 0 e $5^{\circ} \mathrm{C}$, por uma semana.

Segundo WHITE (1982), a causa primária de deterioração do leite pasteurizado refrigerado é o desenvolvimento de bactérias psicrófilas e/ou psicrotróficas, cuja presença em números elevados é, sem dúvida, um dos principais 
responsáveis pela reduzida vida útil do produto, frequentemente inferior a 3 dias. FAIRBAIRN \& LAW (1986), atribuíram a presença de microrganismos psicrófilos e/ou psicrotróficos no leite pasteurizado e refrigerado a uma subpasteurização e má higienização dos equipamentos que entraram em contato com o produto. Portanto, a maneira de se evitar a contaminação por microrganismos psicrófilos e/ou psicrotróficos é realizar uma adequada pasteurização e manter os equipamentos bem higienizados.

Pesquisa realizada por TATINI et al. (1991), demonstrou que usualmente o leite cru, contém bactérias Gram-positivas, oriundas principalmente de úbere mastítico, e que em conjunto vivem bactérias Gram-negativas psicrófilas, provenientes da água de abastecimento e da superfície dos equipamentos, sendo que estas bactérias dificilmente resistiriam à temperatura de pasteurização; portanto, a presença dessas bactérias em leite pasteurizado, sugere recontaminação do produto devido a má higienização dos equipamentos ou, através da água de abastecimento (LOANE, 1969; WHITE, 1982).

Em relação aos microrganismos termófilos, $83,3 \%$ das amostras analisadas (Figura 2-B), tanto para a marca $\mathrm{A}_{1}$ como para a marca $\mathrm{A}_{2}$, apresentaramse fora dos padrões SIPA (1994). Embora alguns autores não os considerem como índice de higiene, a presença destes indica falhas na planta de pasteurização (VESSONI-PENNA et al., 1986). 


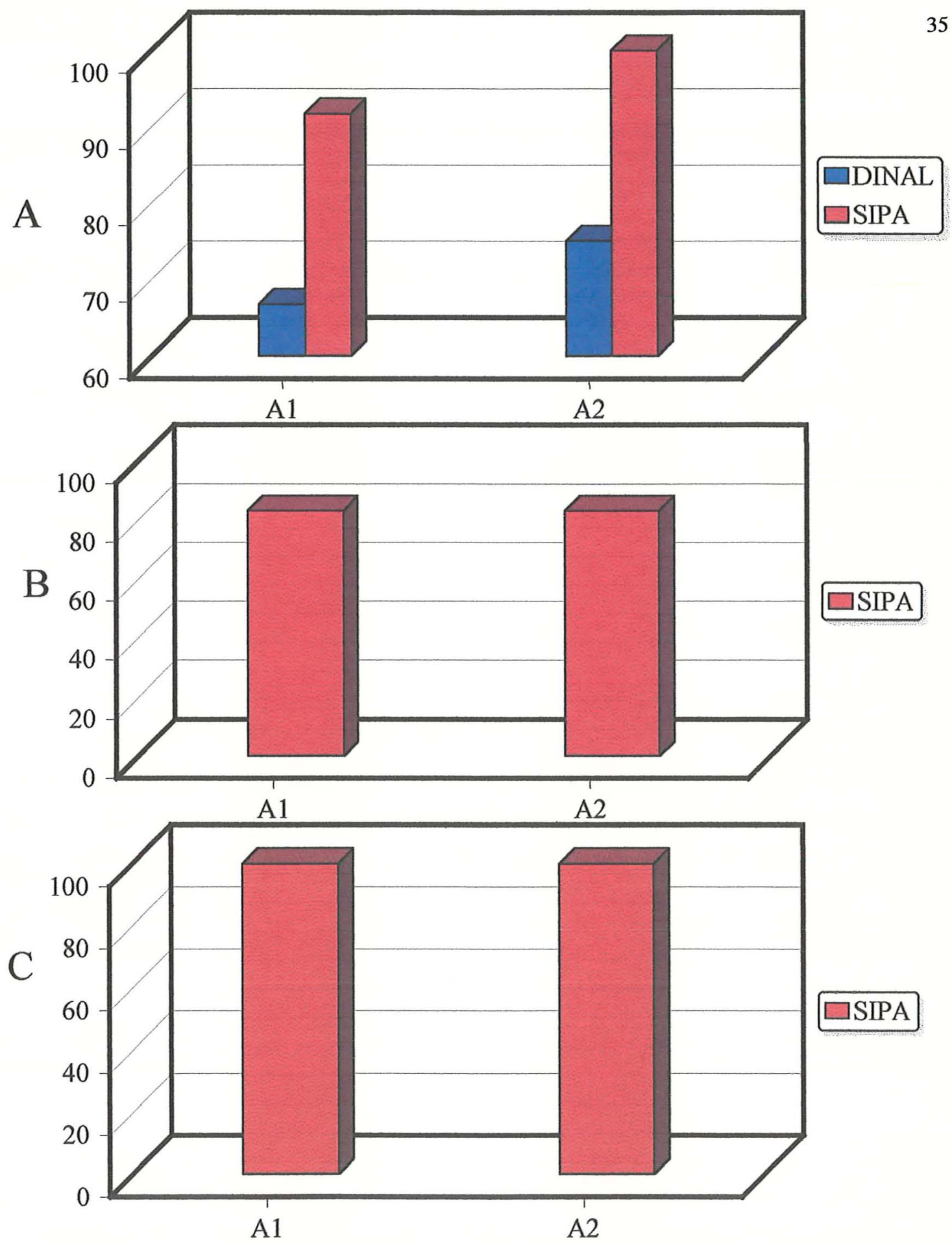

Figura 2 - Porcentagens de amostras analisadas de leite pasteurizado tipo A, das marcas A1 e A2, que se apresentaram fora dos padrões DINAL (1987) e SIPA (1994), para microrganismos mesófilos (A), e SIPA (1994) para termófilos (B) e psicrófilos e/ou psicrotróficos (C). 
Estudos realizados por BENNETT (1993), revelaram que a maior contaminação do leite tipo $\mathrm{A}$, está relacionada com casos de mastite bovina. A mastite é causada por microrganismos que penetram no úbere através do esfíncter das tetas. As lesões causadas nas células produtoras de leite fazem com que a composição do leite se altere, interferindo na qualidade com a elevação da carga microbiana, principalmente dos patogênicos produtores de enterotoxinas resistentes à temperaturas de pasteurização.

A DINAL (1987), não faz referências a padrões para microrganismos psicrófilos e/ou psicrotróficos e termófilos para leite pasteurizado tipo A.

A presença de coliformes totais acima de $1 / \mathrm{ml}$, (Tabela 1) foi constatada em $33,3 \%$ e $25,0 \%$ das amostras, respectivamente, para as marcas $A_{1}$ e $A_{2}$, enquadrando-as fora dos padrões estabelecidos pela DINAL (1987). Pela SIPA (1994), tanto a marca $A_{1}$ como a $A_{2}$ apresentaram 50,0\% das amostras analisadas fora do referido padrão. Do total analisado, tanto para a marca $A_{1}$ como para a $A_{2}$, $100 \%$ das amostras, não apresentaram contaminação por coliformes fecais, conforme mostra também a Figura 3. Segundo HARTMAN \& LAGRANGE (1985), os microrganismos do grupo coliforme não sobrevivem à temperatura de uma pasteurização adequada e a presença destes microrganismos indica com certeza uma recontaminação pós-pasteurização ou higienização inadequada da planta de processamento e utensílios que entram em contato com o produto. 


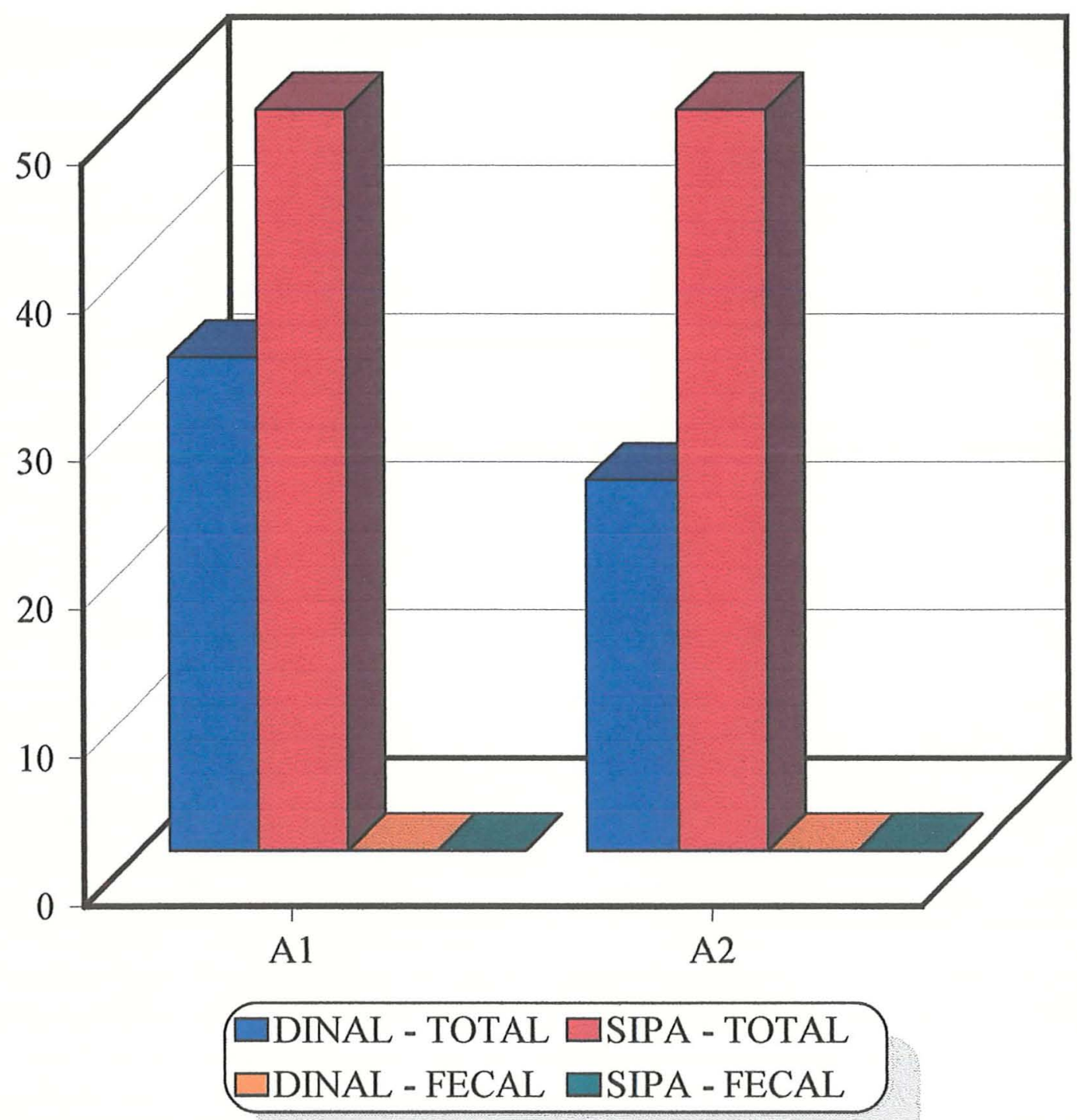

Figura 3 - Porcentagens de amostras analisadas de leite pasteurizado tipo A, das marcas A1 e A2 que se apresentaram fora das especificações dos padrões DINAL (1987) e SIPA (1994), para bactérias coliformes totais e fecais. 
Tabela 3 - Número Mais Provável (NMP) de coliformes/ml nas 24 amostras de leite tipo A.

\begin{tabular}{|c|c|c|c|}
\hline \multicolumn{2}{|c|}{$\overline{A_{1}}$} & \multicolumn{2}{|c|}{$\overline{\overline{A_{2}}}$} \\
\hline \multicolumn{2}{|c|}{ Coliformes } & \multicolumn{2}{|c|}{ Coliformes } \\
\hline Totais & Fecais & Totais & Fecais \\
\hline 1,5 & - & - & - \\
\hline 2,3 & - & 0,36 & - \\
\hline 0,91 & - & 2,3 & - \\
\hline - & - & 0,36 & - \\
\hline 29 & - & 29 & - \\
\hline- & - & 0,36 & - \\
\hline - & - & - & - \\
\hline- & - & - & - \\
\hline- & - & - & - \\
\hline 0,73 & - & 2,3 & - \\
\hline 1,5 & - & - & - \\
\hline - & - & - & - \\
\hline
\end{tabular}

- ausência

Pelos resultados obtidos no presente trabalho, nota-se que o leite tipo $\mathrm{A}$, o qual, em nome de uma melhor qualidade, se reveste de uma série de exigências normativas, está chegando às mãos do consumidor por um preço relativamente alto e com uma qualidade abaixo da esperada e recomendada pelos órgãos de controle e vigilância sanitária. 
Outros países, além do Brasil, apresentam problemas de manutenção da qualidade do leite pasteurizado tipo A. COSTA et al. (1989), por exemplo, citaram que $56,7 \%$ de 120 amostras de leite pasteurizado tipo $\mathrm{A}$, coletadas no comércio de Budapest (Hungria), apresentaram contagem total de mesófilos excedendo a $10^{6}$ UFC/ml e $71 \%$ de 76 amostras coletadas em supermercados na África do Sul, encontravam-se fora dos padrões legais daquele país.

WATROUS et al. (1971) observaram que de 50 indústrias da Pensilvânia (Estados Unidos), o leite pasteurizado tipo A de 48 delas apresentavam contagem total de mesófilos menor que $10^{4} \mathrm{UFC} / \mathrm{ml}$, ou seja, dentro dos padrões legais. Amostras de leite provenientes de indústrias que possuíam boas práticas de limpeza e sanificação, apresentaram baixa contagem total de microrganismos mesófilos e ausência de coliformes e psicrófilos, enquanto que naquelas cujas limpezas eram precárias, as contagens totais de mesófilos e de psicrófilos foram altas.

Pesquisa realizada por MEER et al. (1993) no Oregon, EUA, mostrou que das 59 amostras de leite pasteurizado tipo A analisadas, $34 \%$ apresentaram uma contagem total de mesófilos de $10^{2}$ a $10^{3} \mathrm{UFC} / \mathrm{ml}$, com $12 \%$ das amostras apresentando contagens superiores a $10^{3} \mathrm{UFC} / \mathrm{ml}$ para microrganismos psicrófilos, o que as colocou como fora dos padrões vigentes naquele país.

Pesquisa realizada por SILVEIRA et al. (1988) mostrou que 64,7\% das 51 amostras analisadas de leite pasteurizado tipo A, comercializado na cidade de São Paulo, encontravam-se fora do padrão para a contagem total de mesófilos, enquanto 
que a pesquisa de coliformes, mostrou que $52,9 \%$ das amostras estavam fora do estabelecido pela DINAL (1987). A presença de coliformes fecais foi confirmada em $31,37 \%$ das amostras analisadas, colocando-as como de má qualidade higiênicosanitária e portanto, de risco para o consumo humano.

Ao verificar porcentagens altas de produtos fora dos padrões legais vigentes em relação a coliformes, psicrófilos e/ou psicrotróficos, termófilos e mesófilos, esta pesquisa revela que o leite tipo A oferecido ao consumidor em Piracicaba, apresenta-se em condições higiênico-sanitárias insatisfatórias.

Dados mais satisfatórios foram relatados por THIELMANN (1995), quando avaliou as condições higiênico-sanitárias de quatro granjas leiteiras produtoras de leite tipo A, na cidade de Viçosa, MG. A autora descreve que apenas uma das quatro granjas apresentou problemas na linha de processamento; as demais apresentaram boas condições, operando em conformidade com a Portaria $\mathrm{n}^{0} 17 \mathrm{de}$ 29 de outubro de 1980, da Secretaria de Inspeção de Produto Animal do Ministério da Agricultura - SIPA. Nesta mesma pesquisa, a autora revela que o leite produzido em três granjas, apresentou contagem microbiana total de mesófilos, termófilos, psicrófilos, coliformes totais e fecais dentro dos padrões nacionais.

Nas Tabelas de 4 a 7 , são apresentados os resultados das análises microbiológicas do leite pasteurizado tipos B e C, para microrganismos mesófilos, termófilos, psicrófilos e/ou psicrotróficos, coliformes totais e fecais.

As contagens microbianas obtidas nas amostras de leite pasteurizado tipo B são apresentadas nas Tabelas 4 e 5. 
A Portaria 1/87 do Ministério da Saúde - DINAL, determina que a contagem total de mesófilos, não deve exceder ao limite máximo de $8,0 \times 10^{4}$ UFC/ml de leite pasteurizado tipo B. Do total de 36 amostras analisadas (Tabela 4), $58,3 \%$ apresentaram contagens superiores ao determinado pela DINAL (1987).

Os resultados obtidos para a contagem total de mesófilos (Tabela 4) mostram que a variação encontrada foi de $1,8 \times 10^{4}$ a $5,2 \times 10^{6} \mathrm{UFC} / \mathrm{ml}$ para o leite pasteurizado tipo $\mathrm{B}$, com variações de $2,8 \times 10^{4}$ a $5,2 \times 10^{6} \mathrm{UFC} / \mathrm{ml}, 1,8 \times 10^{4}$ a 1,8 $\times 10^{6} \mathrm{UFC} / \mathrm{ml}$ e $2,3 \times 10^{4}$ a $8,4 \times 10^{5} \mathrm{UFC} / \mathrm{ml}$, respectivamente, para as marcas $\mathrm{B}_{1}$, $\mathrm{B}_{2}$ e $\mathrm{B}_{3}$. A marca $\mathrm{B}_{1}$ apresentou $58,3 \%$ e $75,0 \%$ das amostras fora das especificações, ficando a marca $\mathrm{B}_{2}$ com $50,0 \%$ e $83,3 \%$ e a marca $\mathrm{B}_{3}$ com $66,7 \%$ e 83,3\% das amostras, também não atendendo as exigências normativas dos padrões DINAL (1987) e SIPA (1994), respectivamente, conforme mostrado na Figura 4-A. Analisando todas as amostras das três marcas estudadas, pode-se observar que não há grandes variações, demonstrando que todos os lotes de cada marca estudada, apresentaram problemas em relação a qualidade, devido ao alto índice de amostras fora das exigências normativas da DINAL (1987) e SIPA (1994), para o leite pasteurizado tipo B.

A Secretaria de Inspeção de Produto Animal - SIPA (1994), determina que a contagem de psicrófilos e/ou psicrotróficos no leite pasteurizado tipo B não deve exceder a $10 \%$ do padrão para a contagem total de mesófilos.

A variação encontrada no presente trabalho para microrganismos psicrófilos e/ou psicrotróficos foi de $1,2 \times 10^{2}$ a $4,6 \times 10^{4} \mathrm{UFC} / \mathrm{ml}$, com oscilações 
de $6,7 \times 10^{2}$ a $4,6 \times 10^{4} \mathrm{UFC} / \mathrm{ml}, 1,2 \times 10^{2}$ a $7,6 \times 10^{3} \mathrm{UFC} / \mathrm{ml}$ e $5,5 \times 10^{2}$ a 2,9 $\mathrm{x} 10^{4} \mathrm{UFC} / \mathrm{ml}$, respectivamente, para as marcas $\mathrm{B}_{1}, \mathrm{~B}_{2}$ e $\mathrm{B}_{3}$.

Das 36 amostras de leite pasteurizado tipo B analisadas, 44,4\% apresentaram-se com contaminação por microrganismos psicrófilos e/ou psicrotróficos, acima dos padrões da SIPA (1994).

As marcas $B_{1}, B_{2}$ e $B_{3}$, apresentaram, respectivamente, $58,3 \%, 16,7 \%$ e $58,3 \%$ das amostras analisadas fora das especificações dos padrões da SIPA (1994), conforme mostrado na Figura 4-C. Considerando-se que os microrganismos psicrófilos e/ou psicrotróficos são facilmente destruídos na pasteurização, as marcas de leite tipo B analisadas apresentaram uma contaminação considerável e indesejável por estes microrganismos.

Os microrganismos psicrófilos são capazes de se multiplicarem a uma temperatura de $7^{\circ} \mathrm{C}$ e, de produzirem enzimas proteolíticas, na maioria das vezes termorresistentes; degradam as proteínas do leite e, em números elevados, causam uma série de problemas de sabor e aroma, alterando as características físicoquímicas, tornando o produto impróprio para o consumo humano (COUSIN, 1982; BRITO, 1995). Segundo ADAMS et al. (1975), as unidades de proteases termorresistentes podem promover a coagulação do leite e encurtar a vida útil do produto, sendo portanto, as principais responsáveis pela deterioração do leite armazenado sob refrigeração (MCKINNON \& PETTIPHER, 1983). 


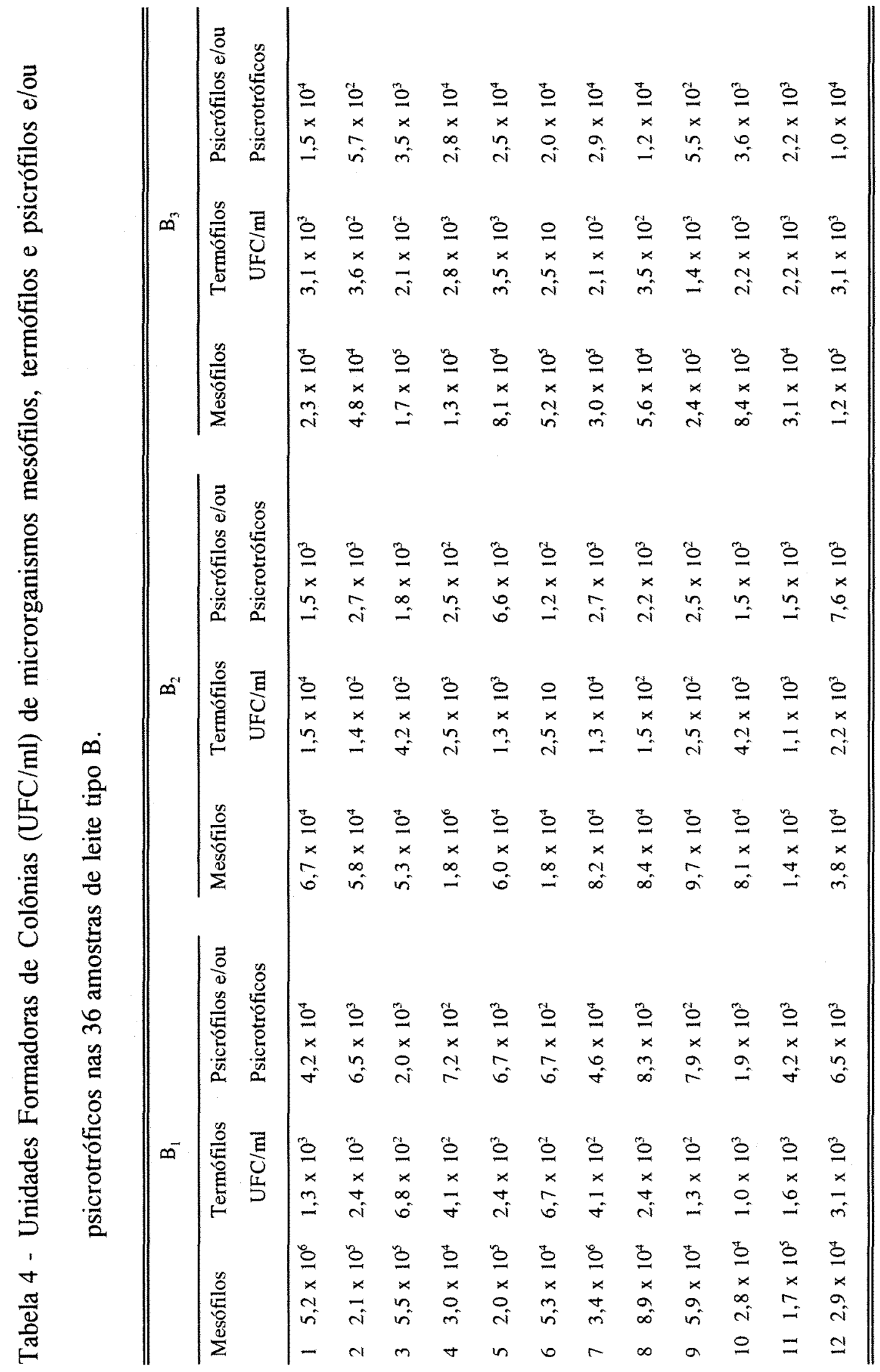


Em relação aos microrganismos termófilos, as contagens encontradas variaram de $2,5 \times 10$ a $1,5 \times 10^{4} \mathrm{UFC} / \mathrm{ml}$, com oscilações de $1,3 \times 10^{2}$ a $3,1 \times 10^{3}$ $\mathrm{UFC} / \mathrm{ml}, 2,5 \times 10$ a $1,5 \times 10^{4} \mathrm{UFC} / \mathrm{ml}$ e $2,5 \times 10$ a $3,5 \times 10^{3} \mathrm{UFC} / \mathrm{ml}$, para as marcas $B_{1}, B_{2}$ e $B_{3}$, respectivamente.

A SIPA (1994) determina que a contagem de microrganismos termófilos no leite tipo $\mathrm{B}$, não deve exceder $10,0 \%$ da contagem total de mesófilos em placas. A marca $\mathrm{B}_{2}$ apresentou $25,0 \%$ das amostras fora das especificações do referido padrão, conforme pode ser notado na Figura 4-B. Todas as amostras analisadas das marcas $B_{1}$ e $B_{3}$, enquadraram-se nos padrões do referido órgão.

Segundo WOUTRES (1983) e VESSONI-PENNA et al. (1986), bactérias termófilas sobreviventes às temperaturas de pasteurização, pertencem na sua maioria à espécies do gênero Bacillus, que produzem esporos resistentes à pasteurização, e são responsáveis por alterações organolépticas e pela coagulação do leite. Segundo BRITO (1995), surtos de intoxicação têm sido relacionados com ingestão de leite contaminado com bactérias pertencentes ao gênero Bacillus.

PANETTA (1984) não considera os microrganismos termófilos como indicadores de insalubridade do leite pasteurizado, quando comparados às mesmas contagens encontradas para microrganismos psicrófilos e mesófilos. No entanto, segundo VESSONI-PENNA et al. (1986) a presença de bactérias termófilas em leite pasteurizado, manifesta falhas no desempenho, manejo e limpeza da planta de pasteurização, local de procedência dessas bactérias. WASHAM et al. (1977) e WESTHOFF \& DOUGHERTY, (1981), atribuem a redução da vida de prateleira do produto à presença de microrganismos termófilos, quando o leite não é mantido sob temperatura adequada de refrigeração. 

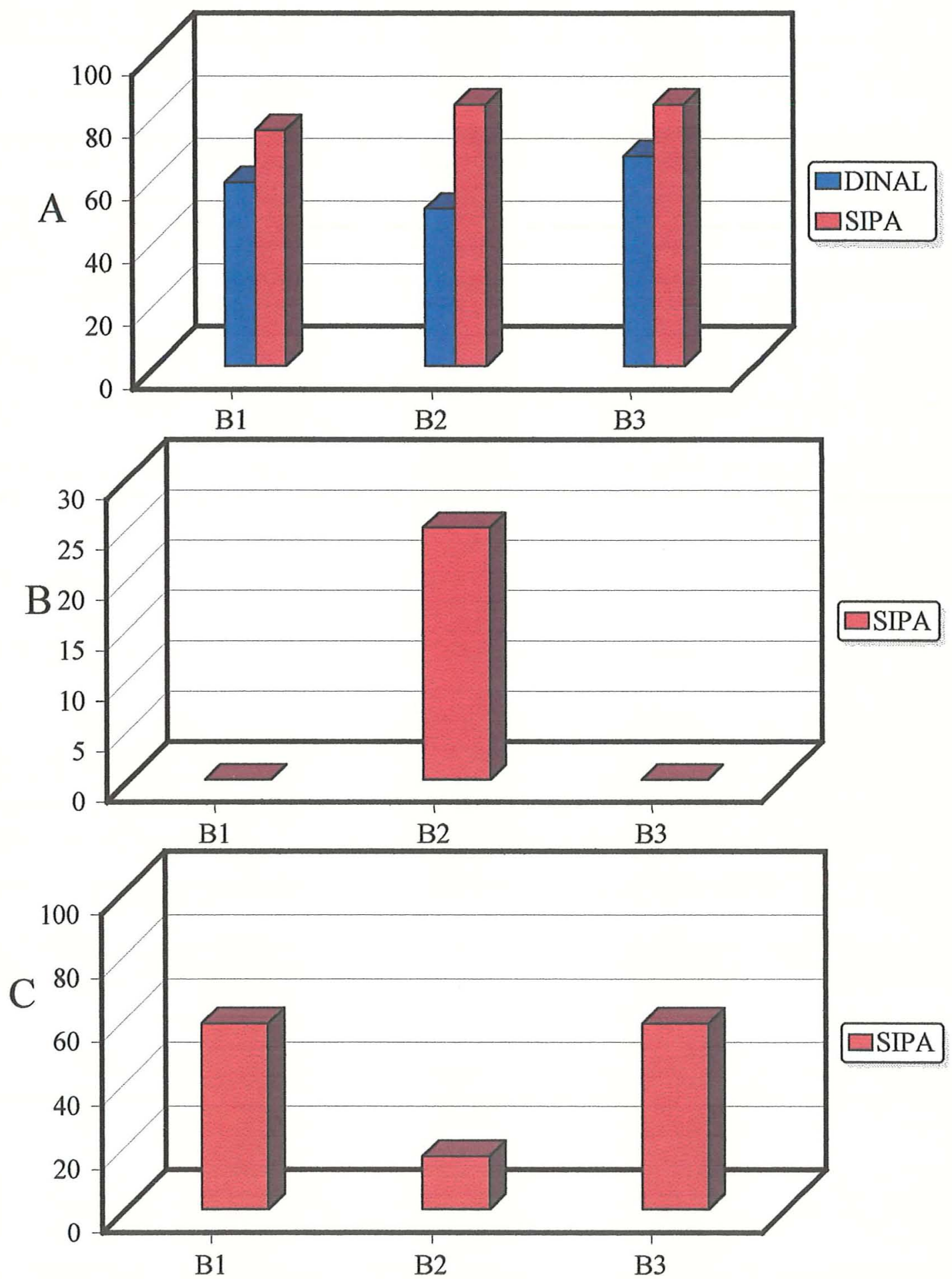

Figura 4 - Porcentagens de amostras analisadas de leite pasteurizado tipo B, das marcas B1, B2 e B3, que se apresentaram fora dos padrões DINAL (1987) e SIPA (1994), para microrganismos mesófilos (A), e SIPA (1994) para termófilos (B) e psicrófilos e/ou psicrotróficos (C). 
A DINAL (1987), não faz referências a padrões para microrganismos psicrófilos e/ou psicrotróficos e termófilos para leite pasteurizado tipo B.

Os microrganismos coliformes crescem bem em grande número de alimentos no intervalo de temperatura de $-2^{\circ} \mathrm{C}$ até $50^{\circ} \mathrm{C}$ (ICMSF, 1978 e SPECK, 1984).

A pesquisa de coliformes totais e fecais, para leite pasteurizado tipo B, realizada pelo método do número mais provável (NMP) de acordo com a Associação Brasileira de Normas Técnicas (ABNT, 1991), é mostrada na Tabela 5, onde nota-se que das 36 amostras analisadas, $72,2 \%$ apresentaram contaminação por coliformes totais, acima dos padrões da DINAL (1987) e 11,1\% apresentaram contaminação por coliformes fecais acima dos mesmos padrões. Quando comparadas com os padrões da SIPA (1994) verificou-se que $86,1 \%$ das amostras analisadas estavam acima do referido padrão para coliformes totais e que $27,8 \%$ das amostras analisadas se encontravam acima do mesmo padrão em relação a coliformes fecais. Analisando as marcas independentemente, todas apresentaram alto índice de contaminação por coliformes; somente a marca $\mathrm{B}_{3}$ apresentou ausência de coliformes fecais em todas as amostras analisadas. Tanto a marca $B_{1}$ como a $B_{2}$, apresentaram $16,7 \%$ das amostras contaminadas com coliformes fecais em índices superiores aos permitidos pela Legislação Brasileira (DINAL, 1987) que é de no máximo $1 / \mathrm{ml}$. Apesar da marca $B_{3}$ não apresentar contaminação por coliformes fecais, a mesma teve um índice de contaminação muito alto em relação a contagem total de mesófilos, psicrófilos e/ou psicrotróficos e de coliformes totais, superando os padrões estabelecidos pela DINAL (1987) e SIPA (1994). 
Tabela 5 - Número Mais Provável (NMP) de coliformes/ml nas 36 amostras de leite tipo B.

\begin{tabular}{|c|c|c|c|c|c|}
\hline \multicolumn{2}{|l|}{$\mathrm{B}_{1}$} & \multicolumn{2}{|l|}{$\mathrm{B}_{2}$} & \multicolumn{2}{|l|}{$\mathrm{B}_{3}$} \\
\hline \multicolumn{2}{|c|}{ Coliformes } & \multicolumn{2}{|c|}{ Coliformes } & \multicolumn{2}{|c|}{ Coliformes } \\
\hline Totais & Fecais & Totais & Fecais & Totais & Fecais \\
\hline$>110$ & 0,3 & $>110$ & 0,91 & 0,91 & - \\
\hline$>110$ & 2,1 & 2,3 & 0,36 & 2,3 & - \\
\hline 0,91 & - & 110 & - & 110 & - \\
\hline 110 & - & $>110$ & - & 9,3 & - \\
\hline 29 & - & 2,3 & - & 9,3 & - \\
\hline 24 & - & 15 & - & 46 & - \\
\hline$>110$ & 2,3 & 46 & 2,8 & 2,3 & - \\
\hline 110 & - & 4,3 & 0,91 & - & - \\
\hline 110 & - & $>110$ & 1,5 & 4,3 & - \\
\hline 2,3 & - & 46 & - & 21 & - \\
\hline- & - & 4,3 & 0,36 & 20,3 & - \\
\hline 110 & - & 0,91 & 0,91 & 24 & - \\
\hline
\end{tabular}

- ausência

As marcas $B_{1}$ e $B_{2}$ apresentaram $75,0 \%$ das amostras analisadas com NMP de coliformes totais/ml, acima dos padrões estabelecidos pela DINAL (1987), que é de no máximo $4 / \mathrm{ml}$. A marca $\mathrm{B}_{3}$ apresentou $66,7 \%$ das amostras analisadas 
com número de coliformes totais superiores ao estabelecido pela DINAL (1987). Quando comparadas as marcas $B_{1}, B_{2}$ e $B_{3}$ com os padrões da SIPA (1994), estas apresentaram $83,3 \%, 91,7 \%$ e $83,3 \%$ das amostras analisadas, fora do referido padrão, que é de no máximo 2 coliformes totais/ml, conforme visualizado na Figura 5. De acordo com esse mesmo padrão, $25,0 \%$ das amostras analisadas da marca $B_{1}$ e $58,3 \%$ das amostras analisadas da marca $\mathrm{B}_{2}$, apresentaram contaminação por coliformes fecais acima das especificações.

A pesquisa de coliformes mostra que as amostras de leite pasteurizado tipo B analisadas foram subprocessadas e possuíam um índice de contaminação muito alto, indicando que as mesmas apresentavam condições higiênico-sanitárias insatisfatórias, revelando um produto impróprio para o consumo humano.

Pesquisa realizada por RODRIGUES et al. (1993) revelou que $76,4 \%$ das amostras analisadas de leite pasteurizado tipo B, encontravam-se fora dos padrões nacionais para coliformes totais e $52,4 \%$ fora dos padrões para coliformes fecais. Resultados semelhantes, foram encontrados por NASCIMENTO et al. (1991), quando concluíram em sua pesquisa, que $73,3 \%$ das amostras estavam fora dos padrões nacionais, das quais $70 \%$ apresentavam-se contaminadas por coliformes fecais. 


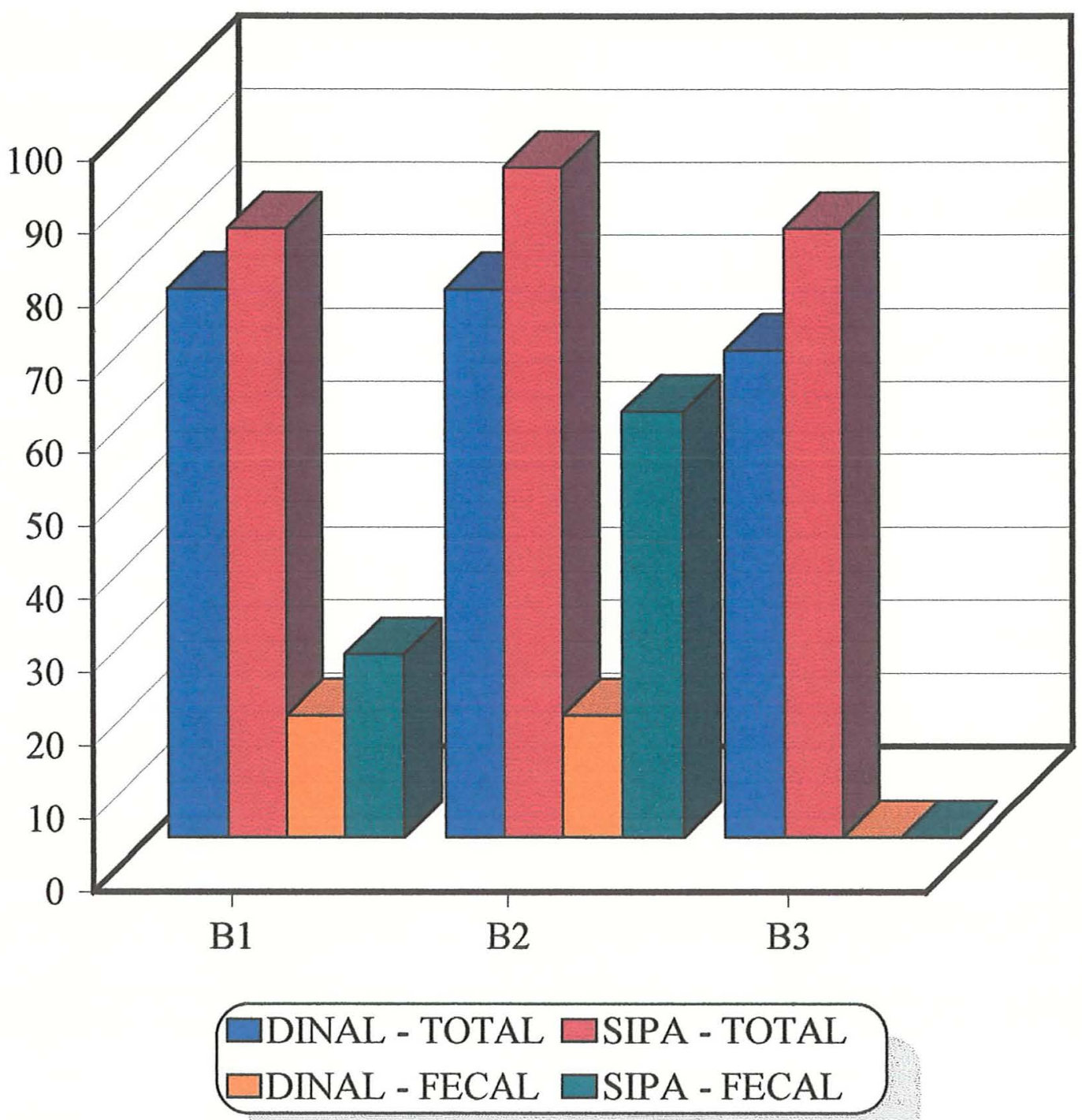

Figura 5 - Porcentagens de amostras analisadas de leite pasteurizado tipo B, das marcas B1, B2 e B3 que se apresentaram fora das especificações dos padrões DINAL (1987) e SIPA (1994), para bactérias coliformes totais e fecais. 
NADER-FILHO et al. (1988) pesquisaram coliformes totais em 80 amostras de leite pasteurizado tipo B, coletadas na saída do pasteurizador, tendo todas elas se enquadrado nos padrões regulamentares. Todavia, $65,0 \%$ das amostras analisadas na saída do envase, mostraram-se fora dos padrões legais. Este fato, segundo os autores, mostra com certeza má higienização dos equipamentos que entram em contato com o leite ou, contaminação através das embalagens.

BARUFALDI et al. (1984), constataram que $65,0 \%$ das amostras de leite pasteurizado tipo B, apresentavam contagens de mesófilos superiores a 4,0 × $10^{4}$ UFC $/ \mathrm{ml} ; 33,0 \%$ e $2,5 \%$ das amostras estavam fora do padrões SIPA (1980) para microrganismos psicrófilos e termófilos, respectivamente. Nesta mesma pesquisa, os autores confirmaram a presença de Escherichia coli em 17,5\% das amostras analisadas.

Considerando os resultados obtidos por BARUFALDI et al. (1984), NASCIMENTO et al. (1991), RODRIGUES et al. (1993), e os resultados obtidos nesta pesquisa, nota-se que a qualidade higiênico-sanitária do leite pasteurizado tipo B deixa bastante a desejar.

Pesquisa realizada por OLIVEIRA \& BORGES (1984) na cidade de Campinas, SP, mostrou o tempo de conservação do leite pasteurizado tipo B, armazenado em refrigerador doméstico. Realizaram a contagem total de mesófilos e o teste de fosfatase. Os números encontrados mostraram que no dia da coleta o 
valor médio era de $3,8 \times 10^{4} \mathrm{UFC} / \mathrm{ml}$, após 24 horas armazenado em refrigerador doméstico, o valor encontrado subia para $6,0 \times 10^{5} \mathrm{UFC} / \mathrm{ml}$ e após 48 horas para 1,2 x $10^{7} \mathrm{UFC} / \mathrm{ml}$ para contagem total de mesófilos. Estes resultados, segundo os autores, indicam uma rápida deterioração na qualidade microbiológica do leite tipo B, e como de um modo geral as contagens atingiram valores acima de um milhão de microrganismos por mililitro, nessas condições quando o leite não chega a coagular, há uma sensível depreciação no sabor, facilmente detectada pelo consumidor. Outro fator importante foi constatar que algumas marcas apresentaram resultados positivos em teste de fosfatase, indicando possíveis deficiências na pasteurização, ou posterior mistura com leite cru.

Segundo BARUFALDI et al. (1984) a qualidade microbiológica do leite recém-ordenhado é própria de cada região. A mistura dos lotes de leites de várias procedências pode vir comprometer a qualidade do lote final, pela introdução de teores microbianos diversos.

O fato de encontrar contagens microbianas tão altas, pode significar leite excessivamente contaminado, sub-pasteurizado, contaminação pós-processo ou exposição do produto beneficiado à temperatura superior a $10^{\circ} \mathrm{C}$ (OLIVEIRA \& BORGES, 1984; BARUFALDI et al., 1984; ROGICK, 1987). Ainda segundo OLIVEIRA \& BORGES (1984), se todos os recursos tecnológicos fossem aplicados de forma adequada, o leite pasteurizado tipo $\mathrm{B}$, alcançaria um período de vida útil de 7 a 10 dias e, de pelo menos 5 dias no refrigerador doméstico. 
Os resultados obtidos nas análises microbiológicas efetuadas nas 48 amostras de 4 marcas diferentes de leite pasteurizado tipo C estão apresentados nas Tabelas 6 e 7 .

A variação encontrada para a contagem total de mesófilos em placa (Tabela 6) para as amostras de leite pasteurizado tipo $\mathrm{C}$ analisadas foi de $5,2 \times 10^{3}$ $\mathrm{UFC} / \mathrm{ml}$ a $1,6 \times 10^{7} \mathrm{UFC} / \mathrm{ml}$, com oscilações de $5,2 \times 10^{3}$ a $6,5 \times 10^{6} \mathrm{UFC} / \mathrm{ml}, 2,4$ x $10^{4}$ a $1,3 \times 10^{6} \mathrm{UFC} / \mathrm{ml}, 1,0 \times 10^{4}$ a $1,6 \times 10^{7} \mathrm{UFC} / \mathrm{ml}$ e $5,1 \times 10^{4}$ a $4,3 \times 10^{6}$ UFC/ml para as marcas $C_{1}, C_{2}, C_{3}$ e $C_{4}$, respectivamente.

Das 48 amostras analisadas (Tabela 6), 33,4\% apresentaram-se com contagens totais de mesófilos acima dos padrões da DINAL (1987), que estipulam como número máximo $3,0 \times 10^{5} \mathrm{UFC} / \mathrm{ml}$ e $81,3 \%$ das mesmas com contagens dos mesmos microrganismos acima dos padrões da SIPA (1994), que estimam como população máxima de mesófilos $5,0 \times 10^{4} \mathrm{UFC} / \mathrm{ml}$.

Das 4 marcas analisadas (Tabela 6), as amostras de número 3 e 7 $(16,7 \%)$ da marca $C_{1} ; 3,9$ e $12(25,0 \%)$ da marca $C_{2} ; 1,5,7,10$ e $11(41,7 \%)$ da marca $C_{3}$ e, $1,4,5,6,7$ e $10(50,0 \%)$ da marca $C_{4}$, apresentaram-se com contagens totais de mesófilos acima dos padrões da DINAL (1987), que estipulam um máximo de $3,0 \times 10^{5} \mathrm{UFC} / \mathrm{ml}$, e portanto as classificam como produtos em condições higiênicas insatisfatórias. 
Em relação aos padrões SIPA (1994), estes índices fícaram em 50,0\%, $83,3 \%, 91,7 \%$ e $100,0 \%$ para as marcas $C_{1}, C_{2}, C_{3}$ e $C_{4}$, respectivamente, conforme pode ser visualizado na Figura 6-A.

De acordo com a Secretaria de Inspeção de Produto Animal (SIPA, 1994), as características bacteriológicas referentes as contagens totais de mesófilos, número de termófilos, psicrófilos e/ou psicrotróficos, teor de coliformes e germes patogênicos deverão ser exigidas até no ato de expedição do produto para o comércio varejista. Entretanto, tais exigências podem estar sendo negligenciadas, o que pode ser verificado (Tabela 1) em função da alta porcentagem das marcas analisadas que mostraram números de alguns desses microrganismos bem acima dos padrões, evidenciando um produto de baixa qualidade higiênica. Caso os produtos analisados não tenham chegado aos pontos de distribuição com a carga microbiana tão elevada, como verificado nas análises, tal acréscimo deverá então ser atribuído às más condições de distribuição, comercialização dos produtos, o que já estaria sob a responsabilidade dos órgãos de saúde pública, dos quais da DINAL especificamente para os produtos em questão. 


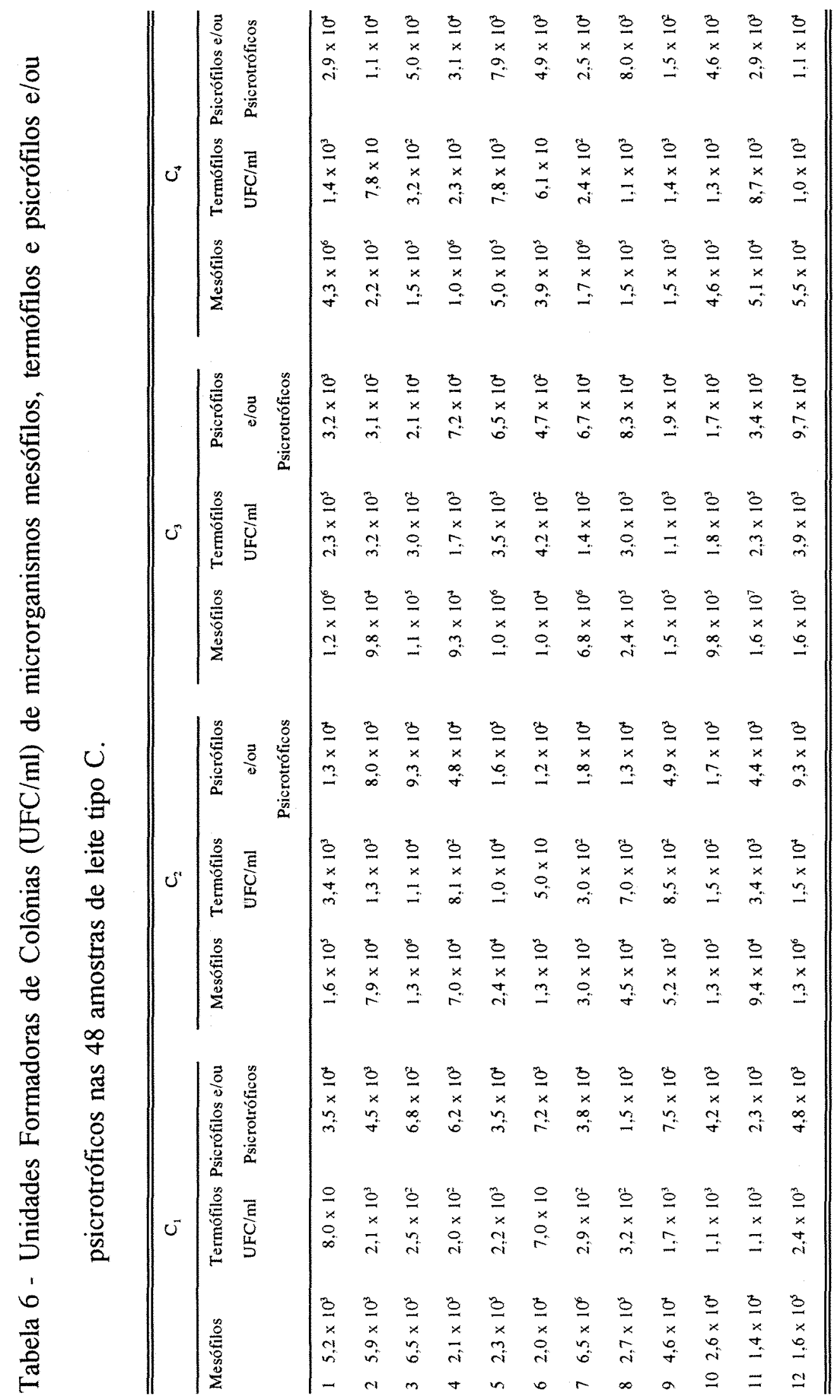


As autoridades de saúde pública é que determinam as condições de manutenção do leite nos estabelecimentos varejistas; tal fato pode não estar recebendo a devida atenção, visto que as marcas analisadas de leite pasteurizado tipo C, apresentaram uma porcentagem elevada de amostras contaminadas por microrganismos mesófilos em índices superiores aos permitidos pelos padrões DINAL (1987). Isso preocupa, por se tratar de um produto perecível e altamente consumido pela população, principalmente em função do baixo poder aquisitivo do povo brasileiro, que encontra no leite tipo $\mathrm{C}$ uma alternativa de compra, o que dificilmente acontece para o leite dos tipos A e B.

Pesquisa realizada por RODRIGUES et al. (1995), em 56 amostras de leite pasteurizado tipo $C$, comercializadas no comércio de Viçosa, MG, constatou que $61,3 \%$ das mesmas se encontravam fora dos padrões legais para contagem total de mesófilos. Na determinação do NMP para coliformes totais, 20,4\% das amostras estavam em desacordo com os padrões vigentes no país. De acordo com os resultados encontrados, os autores atribuíram tantos microrganismos a uma contaminação pós-pasteurização, quando constataram que o teste de fosfatase alcalina foi negativo para todas as amostras analisadas.

A Secretaria de Inspeção de Produto Animal - SIPA (1994), determina que a contagem de microrganismos psicrotróficos no leite pasteurizado tipo $C$ não deve exceder $10 \%$ do limite máximo tolerado para a contagem total de mesófilos em placas, ou seja $5,0 \times 10^{3} \mathrm{UFC} / \mathrm{ml}$. 
A variação encontrada para a contagem de psicrófilos e/ou psicrotróficos nas 48 amostras de leite pasteurizado tipo $C$ analisadas foi de $1,2 \times 10^{2}$ a $3,4 \times 10^{5}$ UFC $/ \mathrm{ml}$, com oscilações de $6,8 \times 10^{2}$ a $1,5 \times 10^{5} \mathrm{UFC} / \mathrm{ml}, 1,2 \times 10^{2} \mathrm{UFC} / \mathrm{ml}$ a 1,7 x $10^{5} \mathrm{UFC} / \mathrm{ml}, 3,1 \times 10^{2}$ a $3,4 \times 10^{5} \mathrm{UFC} / \mathrm{ml} \mathrm{e} 1,5 \times 10^{2}$ a $3,1 \times 10^{4} \mathrm{UFC} / \mathrm{ml}$, para as marcas $\mathrm{C}_{1}, \mathrm{C}_{2}, \mathrm{C}_{3}$ e $\mathrm{C}_{4}$, respectivamente. As marcas $\mathrm{C}_{1}, \mathrm{C}_{2}, \mathrm{C}_{3}$ e $\mathrm{C}_{4}$, apresentaram $50,0 \%, 66,7 \%, 75,0 \%$ e $58,3 \%$, respectivamente, das amostras analisadas fora das especificações legais da SIPA (1994), conforme ilustrado na Figura 6-C.

A marca $\mathrm{C}_{3}$, além de ter sido a que apresentou maior índice de amostras fora dos padrões legais vigentes no país em relação aos microrganismos psicrófilos e/ou psicrotróficos, também apresentou uma contaminação bastante elevada em relação a contagem de microrganismos mesófilos, termófilos, coliformes totais e fecais.

CERQUEIRA-CAMPOS et al. (1983), pesquisaram grupos de microrganismos em leite pasteurizado tipo especial $\operatorname{com} 3,2 \% \mathrm{~m} / \mathrm{v}$ de gordura e concluíram que $30,0 \%$ das amostras analisadas se apresentaram fora do padrão nacional em relação as bactérias psicrófilas, percentual inferior ao encontrado na presente pesquisa onde $62,5 \%$ das amostras de leite tipo $\mathrm{C}$ analisadas estiveram fora dos padrões da SIPA (1994).

No presente trabalho, as contagens de microrganismos psicrófilos e/ou psicrotróficos para o leite pasteurizado tipos A, B e C, se mostraram elevadas. Estes 
dados sugerem que o leite pasteurizado pode ter sofrido recontaminação devido a má higienização dos equipamentos ou através da água de abastecimento, além de problemas no armazenamento a nível de comércio varejista e de um possível subprocessamento, conforme os relatos de WASHAM et al. (1977); WESTHOFF \& DOUGHERTY (1981); COUSIN (1982); WHITE (1982); TATINI et al. (1991); NASCIMENTO et al. (1991) e MEER et al. (1993).

Cepas de microrganismos psicrófilos, podem se multiplicar no leite durante a estocagem, antes e após a pasteurização (MAHARI \& GASHE, 1990; MEER et al., 1993; BRITO, 1995).

Alterações organolépticas indesejáveis ocorrem quando o número de psicrófilos ultrapassa a $10^{6} \mathrm{UFC} / \mathrm{ml}$, conforme observado por SCHRODER (1982), ou então, segundo MOURGUES \& AUCLAIR (1973) e COUSIN (1982), quando este valor é de $1,0 \times 10^{7} \mathrm{UFC} / \mathrm{ml}$, índices esses que felizmente não foram constatados no presente trabalho.

Com relação aos microrganismos termófilos, os resultados obtidos nas contagens dos mesmos (Tabela 6), mostram que a variação encontrada foi de $5,0 \mathrm{x}$ 10 a $2,3 \times 10^{5} \mathrm{UFC} / \mathrm{ml}$, com variações de $7,0 \times 10$ a $2,4 \times 10^{3} \mathrm{UFC} / \mathrm{ml}, 5,0 \times 10$ a $1,5 \times 10^{4} \mathrm{UFC} / \mathrm{ml}, 1,4 \times 10^{2}$ a $2,3 \times 10^{5} \mathrm{UFC} / \mathrm{ml}$ e $6,1 \times 10$ a $8,7 \times 10^{3} \mathrm{UFC} / \mathrm{ml}$, respectivamente para as marcas $C_{1}, C_{2}, C_{3}$ e $C_{4}$. A SIPA (1994) estabelece uma contagem de no máximo 5,0 × $10^{3} \mathrm{UFC} / \mathrm{ml}$ para microrganismos termófilos. Das 48 
amostras de leite pasteurizado tipo $C$ analisadas, $14,6 \%$ apresentaram contagens de termófilos acima do referido padrão. Apenas a marca $C_{1}$ apresentou $100 \%$ das amostras analisadas de acordo com o estabelecido pela SIPA (1994). Das amostras analisadas das marcas $\mathrm{C}_{2}, \mathrm{C}_{3}$ e $\mathrm{C}_{4}$ (Figura 6-B), 25,0\%, 16,7\% e 16,7\%, respectivamente, apresentaram-se com valores de termófilos acima dos padrões da SIPA (1994). A DINAL (1987) não faz referências a um padrão para microrganismos psicrófilos e/ou psicrotróficos e termófilos para leite pasteurizado tipo C.

WASHAM et al. (1977), WESTHOFF \& DOUGHERTY (1981), MAHARI \& GASHE (1990) atribuem a redução na vida de prateleira do leite pasteurizado, a presença de bactérias termófilas oriundas de uma matéria-prima excessivamente contaminada, subprocessamento, utensílios e equipamentos contaminados. 


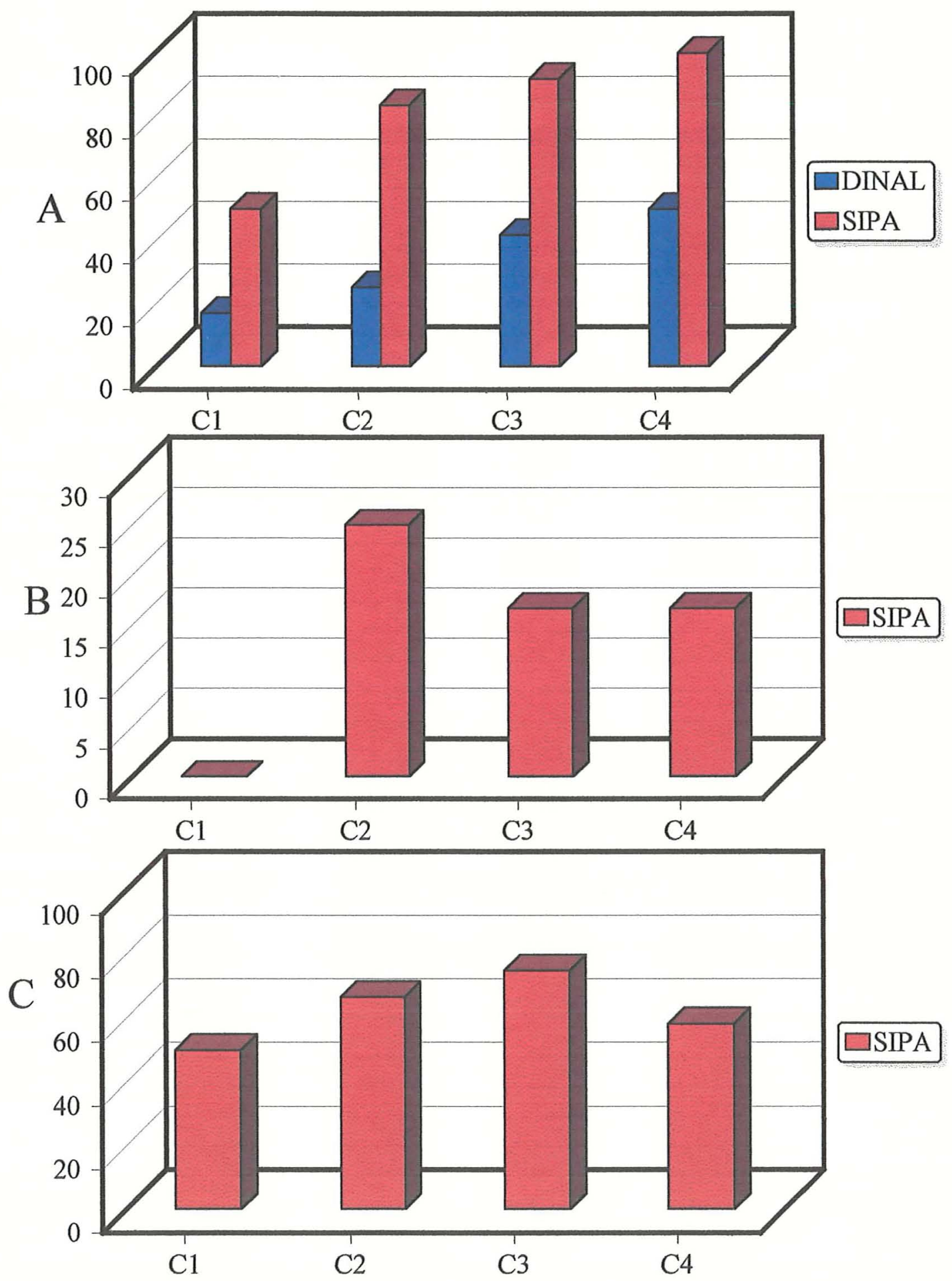

Figura 6 - Porcentagens de amostras analisadas de leite pasteurizado tipo $\mathrm{C}$, das marcas $\mathrm{C} 1, \mathrm{C} 2, \mathrm{C} 3$ e $\mathrm{C} 4$, que se apresentaram fora dos padrões DINAL (1987) e SIPA (1994), para microrganismos mesófilos (A), e SIPA (1994) para termófilos (B) e psicrófilos e/ou psicrotróficos (C). 
A Tabela 7 mostra os resultados obtidos com a pesquisa de coliformes totais e fecais. Analisando cada marca de leite, verifica-se que $16,7 \%\left(\mathrm{C}_{1}\right), 83,3 \%$ $\left(C_{2}\right), 75,0 \%\left(C_{3}\right)$ e $25,0 \%\left(C_{4}\right)$ segundo normas da DINAL (1987), apresentaram contaminação por coliformes totais, acima dos padrões legais brasileiros. As marcas $\mathrm{C}_{2}$ e $\mathrm{C}_{3}$ apresentaram índices muito mais elevados, demonstrando estarem as mesmas em piores condições higiênicas. Ainda, as marcas $\mathrm{C}_{1}$ e $\mathrm{C}_{4}$ apresentaram $100 \%$ das suas amostras perfeitamente enquadradas nos padrões DINAL (1987) para coliformes fecais; a marca $\mathrm{C}_{2}$ teve $25,0 \%$ de suas amostras com a presença de coliformes fecais e a marca $\mathrm{C}_{3}$ com $41,7 \%$, de amostras contaminadas com coliformes fecais, em índices superiores aos permitidos pela legislação brasileira.

As marcas $C_{1}(16,7 \%), C_{2}(100,0 \%), C_{3}(83,3 \%)$ e $C_{4}(33,3 \%)$ apresentaram-se fora das especificações legais da SIPA (1994) para coliformes totais e as amostras das marcas $\mathrm{C}_{2}(58,3 \%)$ e $\mathrm{C}_{3}(50,0 \%)$, fora dos níveis permitidos pelos padrões da SIPA (1994) para coliformes fecais; somente a marca $C_{1}$ apresentou $100 \%$ de suas amostras analisadas com ausência de coliformes fecais e a marca $C_{4}$ com apenas $8,3 \%$ de amostras contaminadas com coliformes fecais, acima dos padrões SIPA (1994), conforme mostrado na Figura 7. As marcas $C_{2}$ e $C_{3}$ apresentaram-se com índices muito altos de contaminação para todos os microrganismos pesquisados, sendo as mais impróprias para o consumo humano, sob o ponto de vista microbiológico. De todas as marcas analisadas, $\mathrm{a}_{1}$ foi a que apresentou menor índice de contaminação, sendo portanto, a melhor marca oferecida ao consumidor das quatro marcas de leite tipo $\mathrm{C}$ analisadas, para os microrganismos pesquisados. 


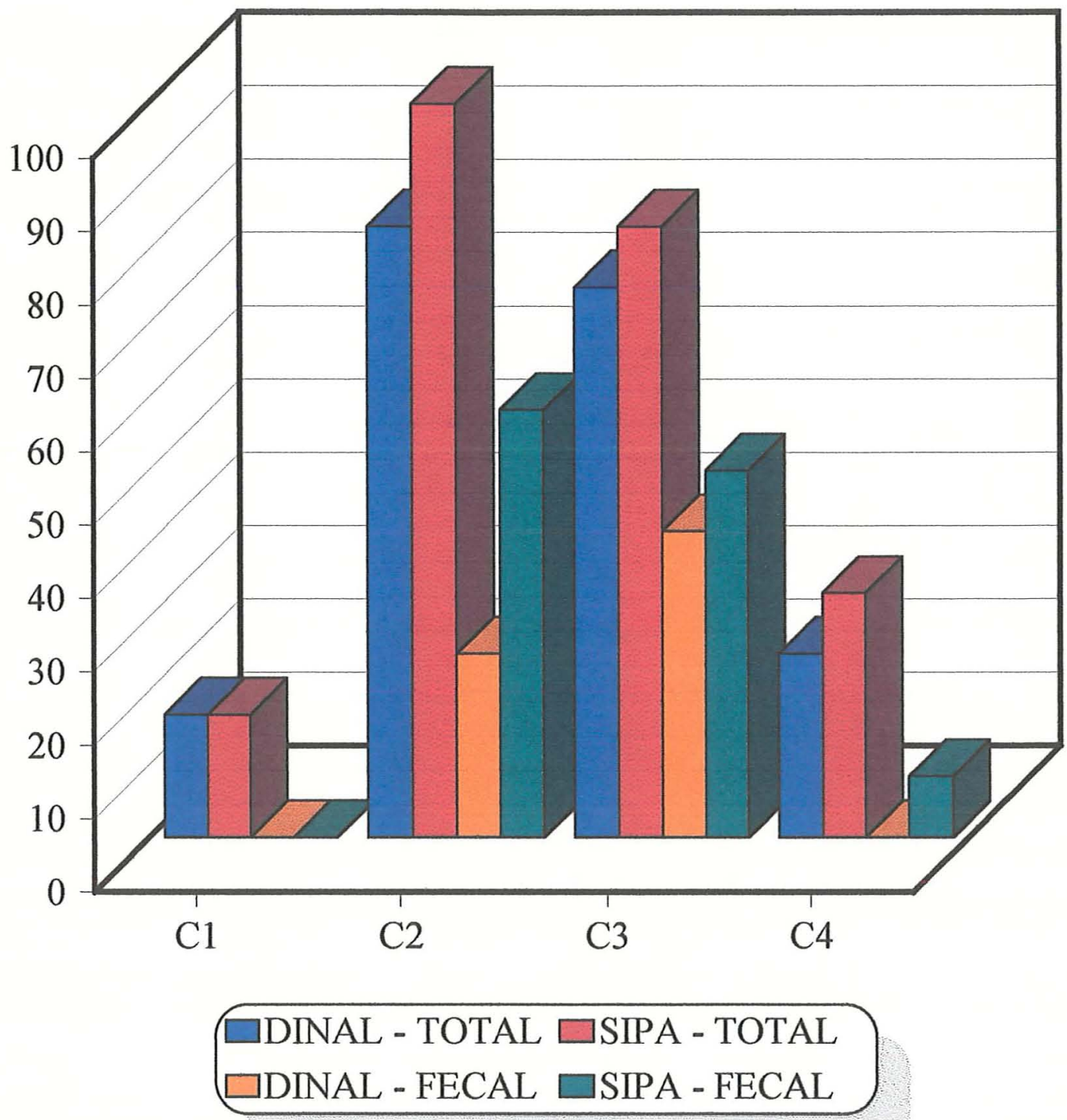

Figura 7 - Porcentagens de amostras analisadas de leite pasteurizado tipo C, das marcas C1, C2, C3 e C4 que se apresentaram fora das especificações dos padrões DINAL (1987) e SIPA (1994), para bactérias coliformes totais e fecais. 
Pesquisa realizada por NASCIMENTO et al. (1991) na cidade de Piracicaba, SP, mostrou a baixa qualidade do leite pasteurizado tipo C, oferecido ao consumidor, quando revelou que das 30 amostras de leite tipo $\mathrm{C}$ analisadas, $66,7 \%$ estavam contaminadas por coliformes das quais $60,0 \%$ por coliformes fecais. Nota-se que tal fato ainda persiste, ao se constatar na presente pesquisa que $50,0 \%$ das amostras de 4 marcas diferentes de leite pasteurizado tipo $\mathrm{C}$, apresentaram contaminação por coliformes totais acima dos padrōes nacionais vigentes (DINAL, 1987) e $16,7 \%$ com contaminação por coliformes fecais acima dos limites estabelecidos pelos mesmos padrões, mostrando claramente más condições higiênico-sanitárias dessas amostras, que se constituem em um produto primordial na alimentação e de grande consumo (principalmente o leite tipo $C$ por questões de custo menos elevado), podendo estar expondo a população que o consome a sérios riscos de toxinfecçōes alimentares.

RIBEIRO et al. (1991) em sua pesquisa relataram que $81,5 \%$ das amostras de leite tipo $\mathrm{C}$ analisadas, encontravam-se contaminadas com coliformes fecais. Dados menos alarmantes foram constatados por HOFFMANN et al. (1994) na cidade de São José do Rio Preto, SP, onde apenas $10,0 \%$ das amostras analisadas apresentaram-se contaminadas por coliformes. No entanto, dados semelhantes aos encontrados por NASCIMENTO et al. (1991), e também aos da presente pesquisa, foram encontrados por TIBANA (1981) ao constatar que 58,3\% das amostras analisadas, estavam fora das especificações da DINAL, para coliformes. 
Tabela 7 - Número Mais Provável (NMP) de coliformes/ml nas 48 amostras de leite tipo C.

\begin{tabular}{|c|c|c|c|c|c|c|c|c|}
\hline & \multicolumn{2}{|c|}{$\mathrm{C}_{1}$} & \multicolumn{2}{|l|}{$\mathrm{C}_{2}$} & \multicolumn{2}{|c|}{$\mathrm{C}_{3}$} & \multicolumn{2}{|l|}{$\mathrm{C}_{4}$} \\
\hline & \multicolumn{2}{|c|}{ Coliformes } & \multicolumn{2}{|c|}{ Coliformes } & \multicolumn{2}{|c|}{ Coliformes } & \multicolumn{2}{|c|}{ Coliformes } \\
\hline & Totais & Fecais & Totais & Fecais & Totais & Fecais & Totais & Fecais \\
\hline 1 & 0,73 & - & 24 & 21 & 15 & 12 & 4,3 & 0,91 \\
\hline 2 & 0,91 & - & 7,5 & - & 46 & 1,5 & - & - \\
\hline 3 & 0,36 & - & 46 & 0,36 & 110 & - & 0,36 & - \\
\hline 4 & 0,73 & - & 110 & - & 4,3 & - & 9,3 & - \\
\hline 5 & - & - & 110 & - & 15 & - & - & - \\
\hline 6 & 24 & - & 24 & - & - & - & - & - \\
\hline 7 & 110 & - & 5,3 & 1,6 & $>110$ & 12 & - & - \\
\hline 8 & 0,91 & - & 24 & 0,91 & $>110$ & 15 & 4,3 & - \\
\hline 9 & 0,36 & - & $>110$ & 21 & $>110$ & 15 & - & - \\
\hline 10 & - & - & 110 & 1,1 & 21 & - & 21 & - \\
\hline 11 & - & - & 24 & - & $>110$ & 2,4 & 46 & - \\
\hline 12 & - & - & 110 & 24 & 9,3 & - & 24 & - \\
\hline
\end{tabular}

- ausência 
A presença de coliformes no leite pasteurizado indica ocorrência de recontaminação ou pasteurização realizada de forma inadequada (PELCZAR et al., 1981). Segundo SILVEIRA et al. (1988); NASCIMENTO et al. (1991), MEER et al. (1993) e HOFFMANN et al. (1994), essas bactérias não são resistentes à temperatura de pasteurização e a presença delas no leite pasteurizado, representa um risco eminente para a saúde do consumidor, além de evidenciar más condições higiênicas do processamento do produto.

A contaminação pós pasteurização exerce uma forte redução na vida de prateleira do leite pasteurizado. No armazenamento sob refrigeração, bactérias psicrófilas são as principais responsáveis por essa redução. A contaminação por apenas uma célula viável na embalagem de um litro, pode levar em apenas um dia, a um grande número de bactérias (LANGEVELD et al., 1973).

A prova da redutase, que se baseia na velocidade de redução de determinadas substâncias por bactérias presentes no leite, geralmente é realizada no leite cru (SANTOS et al., 1984; BEHMER, 1991).

Quanto maior o número de bactérias presentes no leite, menor é o tempo para o descoramento do azul de metileno (VESSONI-PENNA et al., 1986).

Porém, como existem na literatura citações (por exemplo, de JESSOUROUN, 1983) que mencionam que a prova da redutase quando realizada em amostras de leite pasteurizado pode evidenciar uma sub-pasteurização ou 
contaminação pós beneficiamento, na presente pesquisa esta prova foi aplicada às amostras tanto de leite pasteurizado tipo A, como B e C, para se avaliar, juntamente com as outras análises, as condições higiênico-sanitárias das amostras analisadas. Os tempos de descoramento foram superiores a cinco horas em todas as amostras analisadas.

VESSONI-PENNA et al. (1986) aplicaram a prova da redutase ao leite pasteurizado - teor de gordura $3,2 \% \mathrm{~m} / \mathrm{v}$ e verificaram tempos de descoramento menores que 2 horas e 30 minutos em $16,7 \%$ do total de amostras analisadas, as quais, segundo os autores, se fossem aquecidas provavelmente coagulariam.

Segundo OLIVEIRA \& BORGES (1984), o leite pasteurizado apresentase com boa aparência, mas o que conta realmente é a carga microbiana presente no produto. Os produtores, embora hoje melhor orientados, ainda não se habituaram a manter uma sequência de cuidados higiênicos que deveriam ter, principalmente os produtores de leite tipos A e B. Por isso, o leite precisa sair do produtor com o máximo de pureza possível, obedecendo as recomendações dadas pela inspeção e, chegar a usina o mais rapidamente possível, observando todos os cuidados de higiene e preservação.

No presente trabalho, todas as amostras adquiridas nos pontos de pequeno, médio e grande porte de comercialização do produto, foram coletadas no período da manhã, entre 8:00 e 10:00 horas, período este que muitas vezes coincidia com a entrega do produto no estabelecimento de distribuição. Quando foram 
comparados os resultados das análises das amostras adquiridas em pequenos, médios e grandes pontos de venda, não foram observadas grandes variações, com flutuações ocorrendo nos resultados independentemente do porte do estabelecimento comercial. No entanto, pontos de distribuição e comercialização, constituem-se em pontos críticos, uma vez que há falhas no sistema de fiscalização do produto, visto que, muitas vezes, pode ser presenciado nas portas dos estabelecimentos, cestas ou caixas com leite empilhadas, ficando o produto desprotegido, sob a ação de temperaturas elevadas, o que com certeza acarreta graves prejuízos à qualidade do leite. 


\section{CONCLUSÕES}

Os resultados obtidos no presente trabalho, permitem relacionar algumas conclusões sobre as condições microbiológicas do leite pasteurizado distribuído em Piracicaba, SP, no período de janeiro a junho de 1995.

1) As condições microbiológicas das amostras de leite pasteurizado tipos A, $\mathrm{B}$ e C analisadas não foram satisfatórias. A quantidade excessiva dos microrganismos encontrados, pode ser reflexo de uma matéria-prima excessivamente contaminada, de sub-pasteurização, de recontaminação pós-pasteurização ou exposição do produto beneficiado a temperatura inadequada para sua conservação, sendo difícil afirmar no presente trabalho em qual dessas etapas ocorreram falhas, uma vez que só foram analisados produtos finais, já nas prateleiras dos pontos de venda.

2) Como já era esperado, as amostras de leite pasteurizado tipo A, mostraram-se de uma maneira geral em melhores condições higiênico-sanitárias do que as dos tipos $\mathrm{B}$ e $\mathrm{C}$, porém as contagens de microrganismos mesófilos, de 
psicrófilos e/ou psicrotróficos e de termófilos, encontraram-se em altos percentuais das amostras analisadas com números acima dos padrões nacionais vigentes, mostrando assim um produto excessivamente contaminado.

3) Mesmo as amostras de leite pasteurizado tipos $A$ e $B$, que são mais cercados de exigências normativas, se mostraram em más condições higiênicosanitárias, ficando caracterizada uma fraude, onde o consumidor está pagando mais caro a espera de um produto de qualidade bem superior e isso não está ocorrendo nos níveis em que deveria, principalmente entre os tipos $\mathrm{B}$ e $\mathrm{C}$, onde as diferenças praticamente não existiram ou o que é pior, muitas vezes as contaminações foram maiores no leite tipo $\mathrm{B}$ em relação ao tipo $\mathrm{C}$.

4) $O$ alto índice de contaminação por microrganismos psicrófilos e/ou psicrotróficos e por coliformes, sugere a recontaminação do produto após a pasteurização, devido a má higienização e sub-pasteurização, uma vez que tais microrganismos são destruídos na pasteurização.

5) Com base nos resultados do presente trabalho, recomenda-se que sejam realizados estudos de levantamento da microbiota do leite pasteurizado, regularmente, para um monitoramento da qualidade do leite oferecido ao consumo humano e maior rigor dos órgãos responsáveis pela vigilância sanitária, no controle desde a produção até a distribuição do leite. 


\section{REFERÊNCIAS BIBLIOGRÁFICAS}

ADAMS, D.M.; BARACH, J.T.; SPECK, M.L. Heat resistant proteases produced in milk by psychrophilic bacteria of dairy origin. Journal Dairy Science, Champaign, 58:828-34, 1975.

ASSOCIAÇÃO BRASILEIRA DE NORMAS TÉCNICAS - MB 3463. Bactérias coliformes totais, coliformes fecais e Escherichia coli em alimentos Determinação do número mais provável (NMP). Rio de Janeiro, 1991. 7p.

BALLOD, L.B.; BRAMORSKI, A. Influência da fervura doméstica na qualidade microbiológica de leite pasteurizado "tipo C" comercializado em Blumenau, SC. Boletim do Centro de Estudos e Pesquisas do Paraná, Curitiba, 8(2):89-98, jul./dez. 1990.

BARUFALDI, R.; VESSONI-PENNA, T.C.; MACHOSHVILI, J.A.; ABE, L.E. Condições higiênico-sanitárias do leite tipo B vendido na cidade de São Paulo,SP (Brasil), no período de fevereiro a agosto de 1982. Revista de Saúde Pública, São Paulo, 18:367-74, 1984. 
BEHMER, M.L.A. Tecnologia do leite. 15.ed. São Paulo, Nobel, 1991. p.108-111.

BENNETT, $\mathrm{R}$. The case for improving milk quality regulations: milk somatic cell counts. Dairy, Food and Environmental Sanitation, 13(5):278-83, May 1993.

BERGEY's Manual of sistematic bacteriology. Baltimore, Willians \& Wilkins, 1984, v. 1 , cap. 5, p.409-69.

BLANKENAGEL, G. An examination of methods to asses post-pasteurization contamination. Journal of Milk Food Technology, Washington, 39(4):301-4, 1976.

BOCKELMANN, B.V. Processamento asséptico e empacotamento de produtos alimentícios (leite, creme, água, sucos). Revista do Instituto de Laticínios Cândido Tostes, Juiz de Fora, 31(185):11-20, 1976.

BONASSI, A.T. Métodos atuais e modernos para análise do leite e derivados. Revista do Instituto de Laticínios Cândido Tostes, Juiz de Fora, 39(235):1722,1984 .

BRITO, M.A.V.P. Conceitos básicos da qualidade do leite. Revista Leite B, São Paulo, 100:35-42, fev. 1995. 
CARRIÓN, M.G. A Inspeção tem leis avançadas. Leite B \& Derivados, São Paulo, 19:3-5, nov./dez. 1994.

CERQUEIRA-CAMPOS, M.L.; JARIA, S.T.; FURLANETO, S.M.P. Grupos de microrganismos em amostras de leite pasteurizado vendido na cidade de São Paulo. In: CONGRESSO BRASILEIRO DE MICROBIOLOGIA, 12., 1983. Resumos. Sociedade Brasileira de Microbiologia, 1983, p.146.

COSTA, L.C.G.; CARVALHO, E.P.; CARVALHO, A.S. Aspectos higiênicos do leite na fonte de produção, no município de Lavras. Revista do Instituto de Laticínios Cândido Tostes, Juiz de Fora, 38(230):43-46, 1983.

COSTA, L.C.G.; CARVALHO, E.P. de; BONNAS, D.S.; OLIVEIRA JÚNIOR, T.G.; COSTA JÚNIOR, L.C.G. Estudos da qualidade do leite cru e pasteurizado entregues na usina de beneficiamento em Lavras-MG. I. Aspectos microbiológicos. Revista do Instituto de Laticínios Cândido Tostes, Juiz de Fora, 44(261-6):8-13, 1989.

COUSIN, M.A. Presence and activity of psychrotrophic microorganisms in milk and dairy products. A review. Journal of Food Protection, Ames, 45(2):172$207,1982$. 
CRUZ, J.W.B. Doenças transmissíveis ao homem pelo leite e derivados. Revista do Instituto de Laticínios Cândido Tostes, Juiz de Fora, 39(236):33-36, Nov./Dez. 1984.

FAIRBAIRN, J.D.; LAW, A.B. Proteinases of psychrotrophic bacteria: their production, properties, effects and control. Journal of Dairy Research, London, 53(1):139-177, Fev. 1986.

FERREIRA, A.C. A importância do leite e seus derivados. Indústria Alimentar, São Paulo, 2:46-50, 1977.

FRAZIER, W.C.; WESTHOFF, D.C. Microbiologia de los alimentos. 4.ed. Zaragoza, Acribia, 1995. p.649-659

GOMES, M.F. Leite de consumo. Revista do Instituto de Laticínios Cândido Tostes, Juiz de Fora, 30(179):13-15, mai./jun. 1975.

GRIFFITHS, M.W.; PHILLIPS, J.D. Prediction of the shelf life of pasteurized milks at different storage temperatures. Journal of Applied Bacteriology, London, 65(7):269-78, 1988. 
HANKIN, L.; STEPHENS, G.R.; DILlMAN, W.F. Comparison of code dat reliability for fresbily bottled whole, lowfat and not fat fluid milk. Journal of Food Protection, Ames, 43(3): 175-7, 1980.

HARTMAN, A.P.; LAGRANGE, S.W. Coliform bacteria. In: RICHARDSON, G.H., ed. Standard methods for the examination of dairy products. 15.ed. Washington, American Public Health Association, 1985. cap.8, p.173-175.

HARVEY, W.C.; HILL, H. Leche: produccion Y control. Madrid, Ed. Academia, 1989. 595p.

HOFFMANN, F.L.; CRUZ, C.H.G.; VINTURI, M.T.M. Avaliação das características microbiológicas do leite tipo "C" vendido na região de São José do Rio Preto-SP. Boletim do Centro de Estudos e Pesquisas do Paraná, Curitiba, 12(1):17-24, jan./jun., 1994.

HOLSTETTLER, H.; ROTHERNBUHLER, E.; SCHWAB, H. Le Lait; manuel officiel de la Societé Suisse d'industrie laitiérie pour écoles profissionnel les des fromages et laitiers. s.1. Societé Suisse d'Industrie Laitieré, 1978. 153p. 
INTERNATIONAL COMMISSION ON MICROBIOLOGICAL SPECIFICATIONS FOR FOODS. Microorganisms in foods: their significance and methods of enumeration. 3.ed. Toronto, 1978. p.126-137.

JESSOUROUN, E. Grupos de microrganismos em amostras de leite tipo C obtidas em usina de pasteurização (São Paulo, 1982). São Paulo, 1983. 87 p. (Mestrado - Faculdade de Ciências Farmacêuticas/USP).

KORNACKI, J.L.; MARTH, E.H. Foodborne illness caused by Escherichia coli: a review. Journal of Food Protection, Ames, 45(11):1051-67, Nov. 1982.

LANGEVELD, L.P.; CUPERUS, F.; STADHOUDERG, J. Bacteriological aspects of the keeping quality at $5^{\circ} \mathrm{C}$ of reinfected and nonreinfected pasteurized milk. Netherland Milk and Dairy Technology Journal, Netherland, 27(1):54-65, 1973.

LEDFORD, R.A.; SENYK, G.F.; SHIPE, W.F.; KOTSIDESS, E.; WOLFF, E.T. Influence of growth of coliforms on flavor acceptability of commercially processed milk samples. Journal of Dairy Science, Lancaster, 66(8):1611-5, 1983. 
LOANE, P.C. Psychrophiles in farm milks during storage. The Australian Journal of Dairy Technology, Victoria, 24(12):196-9, 1969.

LUCK, H. Bacteriological quality test for bulk cooled-milk: a review. Dairy Science Abstracts, London, 34:101-122, 1972.

LUCK, H.; DYNKELD, M.; BERG, M. Shelf-life tests on pasteurized milk. South African Journal Dairy Technology, Verwoerdburg, 12(3):107-12, 1980.

MAHARI, T.; GASHE, B.A. A survey of the microflora of raw and pasteurized milk and the sources of contamination in a milk processing plant in ADDIG ABABA, Ethiopia. Journal of Dairy Research, London, 57(2):233-238, 1990.

MARTH, E.H. Pathogens in milk and milk products. In: RICHARDSON, G.H., ed. Standard methods for the examination of dairy products. 15.ed. Washington, American Public Health Association, 1985. cap. 3. p.53-4.

MCKINNON, C.H.; PETTIPHER, G.L. A survey of sources of heat resistant bacteria in milk with particular referente to psychrotrophic spore - forming bacteria. Journal of Dairy Research, London, 50(11):163-70, 1983. 
MEER, R.R.; WODBURN, M.J.; BODYFELT, F.W. Identification and characterization of heat-resistant psychrotrophic bacteria in Oregon grade a raw milk. Dairy, Food and Environmental Sanitation, 13(11):631-637, nov. 1993.

MINISTÉRIO DA AGRICULTURA - Secretaria de Inspeção de Produto Animal. Normas para produção e beneficiamento de leite pasteurizado de consumo direto. Portaria $\mathrm{n}^{\circ} 005$ de 14 de abril de 1980.

MINISTÉRIO DA AGRICULTURA - Secretaria de Inspeção de Produto Animal. Normas para produção e beneficiamento de produtos de origem animal. Portaria de 02 de agosto de 1994.

MINISTÉRIO DA SAÚDE. Secretaria de Vigilância Sanitária, Divisão Nacional de Vigilância Sanitária de Alimentos. Portaria 01/87.

MOREIRA, W.S.; SCOTTI, S.; LIMA, C.S.; OLIVEIRA, A.C.; BITENCOURT, A.F. Da necessidade de pasteurização do leite fornecido à população de Santa Maria,RS. Revista Ant. Ciências Rurais, Santa Maria, 1(3):105-122, 1971. 
MOURGUeS, R.; AUClAIR, J. Durée de conservation à $4^{\circ} \mathrm{C}$ et $8^{\circ} \mathrm{C}$ du lait pasteurisé conditionné aseptiquement. Le Lait, Liége, 53(528):481-90, 1973.

NADER-FILHO, A.; ROSSI JÚNIOR, O.D.; SCHOCKEN-ITURRINO, R.P. Pesquisa de Staphylococcus aureus enterotoxigênico em leite de vacas com mastite subclínica. Revista de Microbiologia, São Paulo, v.19, n.4, p.369-373, out./dez., 1988.

NADER-FILHO, A.; SCHOCKEN-ITURRINO, R.P.; ROSSI JÚNIOR, O.D. Avaliação das características microbiológicas do leite $\mathrm{B}$ em diferentes pontos do fluxograma de beneficiamento. In: CONGRESSO NACIONAL DE LATICÍNIOS, 10., Belo Horizonte, 1988. Anais..., Belo Horizonte, Instituto Cândido Tostes, 42p.

NASCIMENTO, G.G.F.; FIGUEIREDO, S.H.M.; UBISSES, O.B.; ANTONELLI, E.M. Condições microbiológicas do leite pasteurizado comercializado em Piracicaba,SP. Boletim da Sociedade Brasileira de Ciência e Tecnologia de Alimentos, Campinas, 25(1);13-21, jan./jun. 1991. 
OLIVEIRA, A.J.; GALLO, C.R.; CARVALHO, C.M. Tratamento térmico do leite acondicionado em filme plástico em banho-maria. Scientia Agricola, Piracicaba, 51(1):175-183, jan./abr. 1994.

OLIVEIRA, J.S. Qualidade microbiológica do leite. Revista do Instituto de Laticínios Cândido Tostes, Juiz de Fora, 31(186):15-20, 1976.

OLIVEIRA, J.S.; BORGES, F.S. Qualidade do leite pasteurizado. Revista do Instituto de Laticínios Cândido Tostes, Juiz de Fora, 39(235):29-33, set./out. 1984.

OLSON JÚNIOR, J.C.; MOCQUOT, G. Milk and milk products. In: INTERNATIONAL COMISSION ON MICROBIOLOGICAL SPECIFICATIONS FOR FOODS - ICMSF. Microbiol ecology of foods. New York, Academic Press, 1980. v.3, p.470-520.

PANETTA, J.C. Qualidade do leite de consumo e fatores interferentes. Higiene Alimentar, São Paulo, 3(3/4):162-66, set./dez. 1984.

PANETTA, J.C. Higiene: qualidade do leite de consumo e fatores interferentes. Leite \& Derivados, São Paulo, 13:34-39, nov./dez. 1993. 
PELCZAR, M.; REID, R.; CHAN, E.C.S. Microbiologia. São Paulo, McGrawHill, 1981. v.2, p.945-60.

REINBOLD, G.W. Bacteriological testing of raw milk and dairy products. Journal of Milk and Food Technology, Washington, 34(12):613-9, 1971.

RIBEIRO, G.A.; ALEIXO, J.A.G.; LIMA, N.B.F. Ocorrência de Escherichia coli enteropatogênicas em produtos láteos comercializados em Pelotas,RS. Boletim da Sociedade Brasileira de Ciência e Tecnologia de Alimentos, Campinas, 25(2):62, jul./dez. 1991.

RODRIGUES, E.L.; RIBEIRO, A. das G.P.L.; LIBERAL, M.H.T.L.; VIDAL, N.M.; SALES, O.F.C. Relação entre as análises físico-químicas e microbiológicas realizadas no leite B empacotado e distribuido no Grande Rio e Niteroi. In: CONGRESSO BRASILEIRO DE MICROBIOLOGIA, 17.; SIMPÓSIO NACIONAL DE FERMENTAÇÃO, 10; ENCONTRO NACIONAL DE MICROBIOLOGIA AMBIENTAL, 4.; SIMPÓSIO BRASILEIRO DE MICOBACTÉRIAS, 5.; SIMPÓSIO ESPECIAL SOBRE CÓLERA, Santos, 1993. Resumos. São Paulo, Sociedade Brasileira de Microbiologia, 1993. p.5. 
RODRIGUES, F.T.; VIEIRA, M.D.; SANTOS, L.J.; PIERRE, S.J.; ARAÚJO, W.C.; ANDRADE, N.J.; BRANDÃO, S.C.C. Características físico-químicas e microbiológicas de leite cru e pasteurizado comercializado em Viçosa, MG. In: CONGRESSO NACIONAL DE LATICÍNIOS, 13, Juiz de Fora, 1995. Resumos. Juiz de Fora, SBM, 1995. p.237-40.

ROGICK, F.A. Produção higiênica do leite. Revista do Instituto de Laticínios Cândido Tostes, Juiz de Fora, 37(221):35-38, 1987.

SAMAGH, B.S.; CUNNINGHAM, J.D. Numerical taxonomy of the genus Pseudomonas from milk products. Journal of Dairy Science, Champaign, 55:1924, 1972.

SANTOS, E.C. dos; VILELA, M.A.P.; SOUZA, H.M. de. Estudo microbiológico do leite para avaliação comparativa das provas de redutase e contagem global. Revista do Instituto Cândido Tostes, Juiz de Fora, 39(236):3-5, nov./dez. 1984.

SCHRODER, M.J.A.; COUSINS, C.M.; McKINNON, C.H. Effect of psychrotrophic post-pasteurization contamination on the keepping quality at 11 and $5{ }^{\circ} \mathrm{C}$ of HTST pasteurized milk in the U.K. Journal of Dairy Research, London, 49(4):619-30, 1982. 
SILVEIRA, N.V.V.; SAKUMA, H.; DUARTE, M.; RODAS, M.A.B.; SARUWATARI, J.H.; CHICOUREL, E.L. Avaliação das condições físicoquímicas e microbiológicas do leite pasteurizado consumido na cidade de São Paulo. Revista do Instituto de Laticínios Cândido Tostes, Juiz de Fora, 43(260):40-45, 1988.

SPECK, M.L. Compendium of methods for the microbiological examination of foods. 2.ed. Washington, American Public Health Association, 1984. 914p.

SPREER, E. Lactologia industrial. 2.ed. Zaragoza, Acribia, 1975. p.3-113.

TATINI, R.S.; MEKALA, P.; EL-HABAZ, A.; GRIFFITHS, M.W. Rapid detection of psychrotrophic, bacteria in manufacturing crad raw milks. Journal of Food Protection, Ames, 54(11):861-867, Nov. 1991.

TERNSTRÖM, A.; LINDBERG, A.M.; MOLIN, G. Classification of the spoilage flora of raw and pasteurized bovine milk, with special reference to Pseudomonas and Bacillus. Journal of Applied Bacteriology, London, 75(1):25-34, July 1993.

THIELMANN, C. Avaliação das características da qualidade e prazo de validade de leite tipo "A". Viçosa, 1995. 127p. (Master Scientia - Universidade Federal de Viçosa). 
THIELMANN, C.; TEIXEIRA, M.A.; CHAVES, J.B.P.; PINHEIRO, A.J.R. Avaliação das características de qualidade e estimativa do prazo de validade do leite tipo "A" estocado a $4^{\circ} \mathrm{C}$ e $8^{\circ} \mathrm{C}$. In: CONGRESSO BRASILEIRO DE MICROBIOLOGIA, 17.; SIMPÓSIO NACIONAL DE FERMENTAÇÃO, 10.; ENCONTRO NACIONAL DE MICROBIOLOGIA AMBIENTAL, 4.; SIMPÓSIO BRASILEIRO DE MICOBACTÉRIAS, 5.; SIMPÓSIO ESPECIAL SOBRE CÓlERA, Santos, 1993. Resumos. São Paulo, Sociedade Brasileira de Microbiologia, 1993. p.6.

TIBANA, A. Estudo bacteriológico do leite comercializado no Rio de Janeiro. Rio de Janeiro, 1981. 123p. (Doutoramento - Universidade Federal do Rio de Janeiro).

VESSONI-PENNA, T.C.; BARUFALDI, R.; COLOMBO, A.J. Estudo das condições higiênico-sanitárias e das características físico-químicas do leite pasteurizado com teor de gordura $3,2 \% \mathrm{~m} / \mathrm{v}$, vendido na cidade de São Paulo. Ciência e Tecnologia de Alimentos, Campinas, 6(1):57-74, 1986.

VIEIRA, D.A. Os microrganismos como indicadores de qualidade. Revista do Instituto de Laticínios Cândido Tostes, Juiz de Fora, 31(185):11-19, 1976. 
VIEIRA, M.B.C.M.; DIAS, S.R.; SOUZA, J.M.; SILVA, S.O. Avaliação da qualidade microbiológica de leites, cru, pasteurizado tipo $\mathrm{C}$ e pasteurizado integral/Fazenda, comercializados em algumas cidades mineiras. 1994. In: CONGRESSO NACIONAL DE LATICÍNIOS, 13., Juíz de Fora, 1995. Resumos. Juíz de Fora: FAPEMIG, 1995. p.139-141.

WASHAM, C.J.; OLSON, H.C.; VEDAMUTHU, E.R. Heat-resistant psychrotrophic bacteria isolated from pasteurized milk. Journal of Food Protection, Ames, 40:101-108, 1977.

WATROUS JR, G.H.; BARNARD, S.E.; COLEMAN, W.W. II. A survey of the actual and potential bacterial keeping quality of pasteurized milk from 50 Pennsylvania dairy plants. Journal of Milk Food Technology, Washington, $34: 145-9,1971$.

WESTHOFF, D.C.; DOUGHERTY, S.L. Characterization of Bacillus species isolated from spoiled ultrahigh temperature processed milk. Journal of Dairy Science, Champaign, 64(2):572-80, May 1981. 
WHITE, C.H. Bacteriological testing a useful tool in prediting fluid milk shelf-life. Journal of Dairy Science, Champaign, 83(5):112-3, 1982.

WOUTRES, J.T.M. Bacillus cereus in milk and milk products. Netherland Milk and Dairy Technology Journal, Netherland, 47(2):61, 1983. 